\title{
A review of scientific research trends within ASPA No. 126 Byers Peninsula, South Shetland Islands, Antarctica
}

\author{
J. BENAYAS ${ }^{1}$, L. PERTIERRA ${ }^{1}$, P. TEJEDO ${ }^{1}$, F. LARA ${ }^{2}$, O. BERMUDEZ ${ }^{3}$, K.A. HUGHES ${ }^{4}$ and \\ A. QUESADA ${ }^{2}$ \\ ${ }^{1}$ Dpto. Ecología, Universidad Autónoma de Madrid, c/ Darwin 2, 28049 Madrid, Spain \\ ${ }^{2}$ Dpto. Biología, Universidad Autónoma de Madrid, c/ Darwin 2, 28049 Madrid, Spain \\ ${ }^{3}$ Centro Nacional de Datos Polares, Instituto Geológico y Minero de España, 28003 Madrid, Spain \\ ${ }^{4}$ British Antarctic Survey, NERC, High Cross, Madingley Road, Cambridge CB3 OET, UK \\ javier.benayas@uam.es
}

\begin{abstract}
Byers Peninsula, Livingston Island, was one of the first sites in Antarctica designated for environmental conservation and scientific protection. Research on Byers Peninsula has been predominantly international, with 88 indexed publications ( $93 \%$ of them published during last 20 years) from 209 authors affiliated to 110 institutions from 22 nations, all of which are signatories to the Antarctic Treaty. Palaeontological research represented $20 \%$ of the published articles. The variety of freshwater bodies within the area has made Byers Peninsula a reference site for limnological studies ( $24 \%$ of papers). The site also contains numerous outcrops and periglacial features relevant to geology, stratigraphy and geomorphology (29\%). Terrestrial biodiversity is extraordinarily high for lichens, bryophytes and invertebrates ( $15 \%$ of articles). Only $5 \%$ of the publications concern research on human activities, including both archaeology and impact monitoring. Glaciology, meteorology and climatology studies represent only $7 \%$ of papers. This work highlights the international and multidisciplinary nature of science conducted on Byers Peninsula in order to promote international cooperation and to provide information relevant for environmental management and conservation.
\end{abstract}

Received 12 April 2012, accepted 21 July 2012

Key words: climate, geology, limnology, Livingston Island, palaeontology, protected areas, terrestrial biodiversity

\section{Introduction}

Byers Peninsula $\left(62^{\circ} 34^{\prime} \mathrm{S}, 61^{\circ} 13^{\prime} \mathrm{W}\right)$ is a protected area of $84.7 \mathrm{~km}^{2}$ in the west of Livingston Island, South Shetland Islands. Climate in the region is characterized by average summer temperatures slightly above freezing point. Precipitation is relatively high with $800 \mathrm{~mm}$ per year, mostly as rain in summer (Ellis-Evans 1996), and winds are moderate compared to other locations (Serrano 2003). As one of the largest areas of ice-free ground in the Antarctic Peninsula (Richard et al. 1994), it contains a remarkable variety of geological formations and ecosystems available for research.

The abundance of Antarctic fur seals (Arctocephalus gazella Peters) in this area attracted sealers in the early 19th century (Lewis Smith \& Simpson 1987). However, the profitability of this activity was quickly reduced by systematic and uncontrolled hunting, and sealers soon left the area. In 1966, part of the Peninsula was designated as the Specially Protected Area (SPA) No. 10 by Recommendation IV-10 of the Antarctic Treaty Consultative Meeting (ATCM). The main aim was to conserve the biological values of the area, which included a high diversity of plant and animal life within a relatively small area. Designation as an SPA was changed in 1975 through Recommendation VIII-2, which redesignated the area as Site of Special Scientific Interest No. 6 (SSSI) (Recommendation VIII-4). The new designation protected three sites on the Peninsula where fossils provided evidence of the former link between other elements of Gondwana and Antarctica. The SSSI was subsequently extended through Recommendation XVI-5 (1991) to include boundaries similar to those of the original SPA, and protecting the scientific use of the biological and archaeological features of outstanding importance found in the Peninsula, in addition to the geological values previously cited. The protection status of the area changed again with its designation as an Antarctic Specially Protected Area (ASPA) No. 126 for the full site adopted in 2001 by Decision 1 (2002). The management plan was adopted by Measure 1 (2002) and recently revised by Measure 4 (2011). ASPA category may be applied both to terrestrial and marine areas to protect outstanding environmental, scientific, historic, aesthetic or wilderness values, any combination of those values, or ongoing or planned scientific research (Protocol on Environmental Protection to the Antarctic Treaty, Annex V, Article 3). As a result of this on-going protected status, human presence has been limited in the past 46 years to scientific activities 
which may have reduced direct human impact in the area and kept it free of human influence relative to other ice-free areas in the vicinity (e.g. Deception Island or Fildes Peninsula, King George Island). During the International Polar Year, Byers Peninsula was defined as an International Reference Site for research on terrestrial, limnetic and coastal ecosystems (Quesada et al. 2009).

The majority of ASPAs within the Antarctic Treaty area are small (with over 55\% having an area of less than $5 \mathrm{~km}^{2}$ ) and many protect only a single or limited number of values (Hughes \& Convey 2010). ASPA No. 126 Byers Peninsula does not fit this mould. Unusually for a predominantly ice-free terrestrial ASPA, it is of a much larger scale and contains one of the most diverse ranges of values considered to be worthy of protection within the ASPA network. A challenge to environmental managers is to ensure that Byers Peninsula is protected in a way that considers and facilitates conservation of all of the values within the area. Mainly, this is undertaken through the Byers Peninsula ASPA Management Plan, which has the United Kingdom, Chile and recently Spain as proponent Parties. The management plan describes the values to be protected as: i) the exceptional diversity of terrestrial flora and fauna, ii) the numerous lakes, freshwater pools and streams, iii) the invertebrate fauna, iv) the abundant cyanobacterial mats, v) the diverse breeding avifauna, vi) the lake sediments for use in palaeoenvironmental research, vii) the well preserved subfossil whale bones, and viii) the exposed Jurassic and Cretaceous sedimentary and fossiliferous strata.

The present study aims to i) serve as a compendium of Byers Peninsula science as a reference for future research, ii) analyse the diversity of investigations undertaken and the links between researchers, and iii) identify key aspects for practical conservation of the site. We reviewed all available scientific literature relating to this site, conducted a bibliometric study of the scientific output to identify international research cooperation between the Antarctic Treaty Parties then attempted to identify the emerging issues for practical environmental management and conservation at this site.

\section{Material and methods}

To fullfil these objectives an initial consultation was made of the bibliographic database Thomson's Scientific Citation Index (SCI). SCI is a widely accepted international citation system of more than 4000 peer-reviewed scientific and technical journals. Similar analyses to the present work have been made for Antartic science papers by Dastidar (2007). All published papers that included science on or about Byers Peninsula were included in this review. The list was filtered to determine which were directly related to active research in Byers Peninsula. From the original list we eliminated all those papers with no research directly conducted in Byers Peninsula, such as those that indirectly cited Byers
Peninsula publications, for instance, by comparison of data from elsewhere with Byers Peninsula research findings. In addition, relevant documents from other sources were included in this review in order to summarize current knowledge of Byers Peninsula. We used different tools for their detection, such as the Cold Regions Bibliography Project (www.coldregions.org), and several databases included by Antarctic national programmes on their own websites. References in each selected work were reviewed to detect other studies developed on Byers Peninsula. Finally, some distinguished experts were asked to review and complete the list of identified publications.

Next, a bibliometric analysis was performed on those publications included in the indexed journals of SCI. It is important to recognize that several relevant works on Byers Peninsula may have published in journals not included in SCI. Eight thematic areas were defined based on the main research conducted by the scientific field expeditions. These were: i) Glaciology, Climate and Meteorology, ii) Geology and Stratigraphy, iii) Geomorphology and Soils, iv) Palaeontology, v) Terrestrial Biodiversity, vi) Limnology and Microbiology, and viii) the Human Dimension. Each article was allocated to one of the eight categories. Articles within this special issue have not been included in this analysis, although they may be considered a valuable reference for future research within Byers Peninsula. Changes in the level of scientific outputs were plotted by thematic area, and results were compared with article production across all of Antarctica over the same period. Techniques to determine the extent of collaboration between international researchers (Cross et al. 2002) were used to analyse scientific articles with joint authorship within SCI. The collaboration networks between i) researchers, ii) institutions, and iii) nationalities were derived.

\section{Science summaries from the published papers}

\section{Research on glaciology, climate and meteorology}

Everett (1971) proposed at least three glacial events for Livingston Island, which had a decreasing intensity. The specific climate history and deglaciation chronology of Byers Peninsula have been described by several authors using lake sediments analysis. John \& Sugden (1971) proposed that Byers Peninsula was largely free of permanent ice by 9700 yr BP, whereas Björck et al. (1991a, 1991c, 1993, 1996), Hjort et al. (1992) and Björck \& Zale (1996), suggested a more recent general deglaciation of central Byers Peninsula of around 4000-5000 yr BP. But Björck et al. (1991b) pointed out the problems of ${ }^{14} \mathrm{C}$ dating in Antarctica due to the reservoir effect and the need for a careful evaluation of the proposed radiocarbon dates. Other researchers have used ice rafted detritus from raised beach ridges on Byers Peninsula to analyse this issue (Hall \& Perry 2004). This material was used by Hall (2010) 
to determine the nature and timing of glacial and climate fluctuations in Antarctica relative to those in the rest of the Southern Hemisphere. Data showed a complex pattern characterized by ice transgressions over the area at $\sim 6000-7000$ and $\sim 400 \mathrm{yr}$ BP, which may have been linked to glacial advance. Other works have focused on earlier series of the Quaternary system. Hall (2003) reviewed ice fluctuations during the late Pleistocene glaciation in the South Shetland Islands, including data obtained on Byers Peninsula. Recent studies suggest the deglaciation of some capes and peninsulas at around $9500 \mathrm{yr}$ BP, a regional advance between 6000 and $4500 \mathrm{yr}$ BP (Hall 2009, Michalchuck et al. 2009) and a last small advance of ice domes and ice occupying the cirques during the Little Ice Age (López-Martínez et al. 2012). Growth rings in Cretaceous and Tertiary wood from different sampling sites, including Byers Peninsula, were also used by Francis (1986) to analyse the climate in those periods.

Current meteorology at this site was described by Bañon (2004) and Bañón et al. (2006) highlighted a higher temperature on Byers Peninsula compared with other very close locations (e.g. Juan Carlos I Station) and proposed the existence of a warmer microclimate, with both average temperatures over $0^{\circ} \mathrm{C}$ and abundant precipitation as rain in summer. Before these publications, descriptions of Byers Peninsula climate were generally vague (i.e. Ellis-Evans 1996, Serrano 2003), or were very specific studies such as those conducted by Hall (1992a, 1992b, 1993a, 1993b), who analysed the relationship of various rock surface temperatures to local climatic conditions and the annual number of air freeze-thaw cycles in summer. Rochera et al. (2010) pointed out that inter-annual variation in the meteorological conditions at this site could be significant, acting as a triggering factor for some limnological processes. The latest contribution by Bañon et al. (2013), proposed the use of regional weather data for landscape studies within Maritime Antarctica on the basis of their research on Byers Peninsula.

\section{Geology and stratigraphy}

To the best of our knowledge, the first reconnaissance geological survey of Byers Peninsula was carried out by Hobbs (1968), who described agglomerates near Start Point and andesite lavas with interbedded sediments on the northern shores of New Plymouth. Hobbs attributed the rocks of this location to the Oligocene, probably because these agglomeratic rocks were petrographically similar to some from Point Hennequin, King George Island (Thomson 1992). The discovery of ammonites (Spitceras) belonging to the upper Titonian to Neocomian by González-Ferrán et al. (1970) on the coast of President Beaches eventually proved that parts, at least, were Early Cretaceous in age. Dalziel et al. (1970) also demonstrated the presence of Mesozoic rocks through the analysis of the ammonite fauna in sediments. Valenzuela \& Hervé (1972) divided the Byers Peninsula into two areas. A "younger unit", composed mostly of agglomerates, overlies the "older unit" which is a fossiliferous sedimentary sequence, grading laterally from west to east, from marine to continental facies. These authors also produced the first 1:20 000 geological map of Byers Peninsula and described some patterned ground shapes. This proposal was extended by Pankhurst et al. (1979), who suggest that the unfossiliferous "younger unit" described by Valenzuela \& Herve (1972) is in part a time correlative of the upper (non-marine) facies of the "older unit". Lava flows and intrusions in the main non-marine outcrop are of Lower Cretaceous age, and igneous activity on Byers Peninsula concluded with dolerite plug and sill formation in Upper Cretaceous times. Pankhurst et al. (1979) reported K-Ar ages within the range 126-75 Ma from igneous rocks sampled on Byers Peninsula and provided a second geological sketch map. This geochronology was supported by further discoveries of Berriasian and Valanginian ammonite faunas at many localities throughout western and north-east Byers Peninsula (e.g. Hernández \& Azcárate 1971, Covacevich 1976, Smellie et al. 1980, Askin 1983). Gracanin (1983) suggested that certain strata of Byers Peninsula were much older (Oxfordian) than previously reported $(143 \pm 5 \mathrm{Ma})$. At that time, Hansom (1979) obtained a radiocarbon age of between 2100 and $2400 \mathrm{yr}$ BP for skeletal material from the $10 \mathrm{~m}$ high beach ridge at South Beaches, whereas the lowest beach deposits were dated at $300 \mathrm{yr}$ BP (John \& Sugden 1971, Sugden \& John 1973).

Smellie et al. (1980) studied the geology of this site and assign the Byers Peninsula succession to a single major unit, the Byers Formation, which they divided into four members: Mudstone, Mixed Marine, Agglomerate, and Volcanic (Thomson 1992, Machado et al. 2005a). Lower Cretaceous rocks at Byers Peninsula were examined by Watts et al. (1984), Grunow (1993), and Poblete et al. (2011), showing uncertainties in the exact age of the main event of remagnetization, which could have been acquired during the Cretaceous Normal Chron. Crame et al. (1993) reviewed the previous stratigraphical work on Byers Peninsula and elevated Byers Peninsula to group status, dividing the strata previously assigned to the Mudstone and Mixed Marine members into four formations: Anchorage, Devils Point, President Beaches, and Chester Cone (Machado et al. 2005a). Arche et al. (1994) analysed the internal deformation processes affecting the Mixed Marine member of the Byers Formation, whereas Calvet et al. (1994) dated ash layers in several glaciers on Livingston Island and used the studies of lacustrine sediments of Byers Peninsula to conclude that the lowest layers may correspond to eruptions which occurred at the beginning of the 19th century. Hodgson et al. (1998) analysed lake sediment cores from Midge Lake for volcanic tephra, identifying five horizons. Four of these consisted of sodic basaltic to basaltic-andesitic glasses, and the fifth was a single acidic tephra, located on the top surface, at $2-3 \mathrm{~cm}$. These volcanic materials derived from the Quaternary 
Deception Island volcano. Hathway (1997) proposed that the Upper Jurassic-Lower Cretaceous rocks of the Byers Group record the expansion of Gondwana-margin continental-arc facies into a marine intra-arc basin, and described in detail the Cerro Negro Formation, which appears to form part of an Early Cretaceous episode of arc-perpendicular extension. Arche et al. (1997) completed the study on the continental platform sediments in the Anchorage Formation, describing a wave-dominated outer shelf evolving towards an inner shelf with shoreface bars. These deposits were previously interpreted by Pirrie \& Crame (1995) as deep marine sediments deposited at 1000 or more metres below sea level. González-Casado et al. (1997) established the main characteristics of fracturation in several outcrops around the central part of the Bransfield Basin, including most of the Byers Peninsula. Based on the facial study of a carbonate volcanic sequence, Cabaleri et al. (1997) proposed a shallow lacustrine environment subjected to an arid climate with seasonal rainfall and the presence of considerable organic matter at Byers Peninsula. Zheng et al. (1995, 1998a, 1998b) published several papers in Chinese journals summarizing the geology, volcanology and petrology of Livingston Island, although these studies provided few new insights into the geology of the Byers Peninsula.

Hathway \& Lomas (1998) revised and extended the proposed scheme by Smellie et al. (1980) and Crame et al. (1993) completing the description that now is accepted for this area, which states that the bedrock of this location is composed of Upper Jurassic to Lower Cretaceous marine sedimentary, volcanic and volcaniclastic rocks, intruded by igneous bodies. Byers Peninsula forms part of a MesozoicCenozoic magmatic arc complex which is exposed throughout the whole of the Antarctic Peninsula region. The idea of a lacustrine environment was reintroduced by Pimpirev \& Vangelov (1999), who studied eight types of lithofacies to propose a series of delta palaeoenvironments which could be interpreted as an example of ancient subaqueous segment of deep-water mouth bar type delta system. Kiessling et al. (1999) revised the regional stratigraphy using data from co-occurring radiolarians and ammonites in Upper Jurassic sequences of the Antarctic Peninsula. Depositional processes on the President Beaches Formation and implications for slope apron depositional models were analysed by Lomas (1999). Oteíza (1999) went into the analysis of the Cerro Negro Formation obtaining a $\mathrm{K}-\mathrm{Ar}$ age of $78 \pm 5 \mathrm{Ma}$ on a basaltic plug, whereas Yoo \& Choe (2000) studied the sandstones of the Lower Cretaceous President Beaches Formation to infer the lithology and tectonic settings of this area. Demant et al. (2004) and Machado et al. (2005a) summarized and extended previous studies about the geochronology of the igneous rocks of Byers Peninsula. Machado et al. (2005b) analysed the isotope data and trace element concentrations for volcanic and plutonic rocks from the South Shetland Arc, including some samples from Byers Peninsula.
Geochronology and palaeontological content of the Cerro Negro Formation were summarized by Parica et al. (2007). The tectonic and morpho-structural evolution of this site was described in detail by Alfaro et al. (2010). These authors analysed more than 1200 lineaments, and 359 fault planes from 16 sites, both in sedimentary and intrusive igneous rocks, with a length varying between 31 and $1555 \mathrm{~m}$. Statistical analysis of lineaments and mesoscopic fractures showed a NW-SE maximum trend, with two NE-SW and ENE-WSW secondary maximums. Finally, Toro et al. (2013) reviewed the chronostratigraphy of the sedimentary record of Limnopolar Lake on Byers Peninsula, updating the available knowledge.

\section{Geomorphology and soils}

Thomson (1992) pointed out that Byers Peninsula is one of the most important areas of the South Shetland Islands from a geomorphological point of view. John \& Sugden (1971) studied at length the Holocene beach succession and other geomorphic issues, describing a landscape dominated by a series of marine erosional platforms the highest of which, together with some upstanding volcanic residuals, forms the central part of the peninsula. Rock glaciers and patterned ground at around $10 \mathrm{~m}$ a.s.l. exists on Byers Peninsula (Araya \& Hervé 1972a, 1972b). Fluvial and periglacial processes are dominant presently, and there are few glacial landforms (López-Martínez et al. 1996a). The presence of moraines, one of the most common glacial formations, has been suggested as scarce and only three residual glaciers remain on Ray Promontory, covering less than $0.5 \mathrm{~km}^{2}$ in total (Martínez de Pisón et al. 1996a). A detailed description of periglacial processes and landforms in the South Shetland Islands, including Byers Peninsula area, was recently published by López-Martínez et al. (2012).

Glaciology on Byers Peninsula has been studied by other authors, such as Orheim (1971) and Curl (1980). The former developed a mass balance programme on the small ice cap terminating on Byers Peninsula, on the western side of the island, and the latter reviewed the glacial history for this location. Hall (1994) analysed the role of snow cover on the spatial distribution of sorted stripes. More recently, Cuchí et al. (2004) described the physicochemical properties of various waters in a permafrost area of Byers Peninsula, and Fassnacht et al. (2010) studied the effect of aeolian deposition on the surface roughness of melting snow. Byers Peninsula was recently included in the CALM (Circumpolar Active Layer Monitoring) programme, locating a new CALM-S site near the south-west shore of the Limnopolar Lake (De Pablo et al. 2010, Vieira et al. 2010). This research aims to study and monitor the temporal evolution of the maximum active layer depth in different places and climates where permafrost exists. A complete analysis of the interannual variability of the active layer of this site was recently presented by 
De Pablo et al. (2013). The knowledge about this area was extended by Fassnacht \& Toro (2013), who expanded their previous studies and produced a map of the snow cover and snow depth across the Limnopolar Lake watershed.

Different geodetic and topographic surveys have been carried out by several research groups (SGE et al. 1993, Hernández-Cifuentes 1994), but the most detailed geomorphological map of Byers Peninsula was produced by López-Martínez et al. (1995, 1996a). These authors produced a map that included an explanatory text (Thomson \& López-Martínez 1996) with chapters on topography (Hernández-Cifuentes et al. 1996), geomorphology (LópezMartínez et al. 1996b), glacial features (Martínez de Pisón et al. 1996a), periglacial and nival landforms and deposits (Serrano et al. 1996), fluvial and lacustrine landforms and deposits (Ellis-Evans 1996, López-Martínez et al. 1996c), emergent and submerged marine landforms and deposits (Arche et al. 1996), upper Holocene tephrochronology (Björck \& Zale 1996), palaeoclimate (Björck et al. 1996) and geomorphological evolution (Martínez de Pisón et al. 1996b). The humid maritime climate of the area, with snow and ice melting in summer, favours the development of an important drainage network (Birnie \& Gordon 1980, LópezMartínez et al. 1996c). Also the existence of 110 lakes and pools large enough to be mapped at 1:25 000 scale and occupying $1.5 \%$ of the area of the Peninsula is remarkable (López-Martínez et al. 1996c).

Lithosols are dominant on Byers Peninsula, with permafrost widespread below an active layer of $30-70 \mathrm{~cm}$ depth (Thom 1978, Ellis-Evans 1996, Serrano et al. 1996), although Cryosols and Leptosols are also present (Navas et al. 2005). A $10-20 \mathrm{~cm}$ deep layer of organic matter is present beneath some of the moss and grass communities, without deep accumulations of peat (Bonner \& Lewis Smith 1985). Cryogenic processes, including the mechanical disintegration of bedrock, play a key role in soil development, but lixiviation and other chemical weathering processes were also involved in soil evolution although limited in extent due to the restriction of water circulation in the summer months (Navas et al. 2006, 2008). An initial study on the soils of Byers Peninsula was presented by Henríquez (1994). Ellis-Evans (1996) located some ornithogenic soils in the Devils Point vicinity and on a number of knolls along President Beaches. Navas et al. (2005) carried out a preliminary survey on the content of radionuclides in soils of Byers Peninsula, detecting certain variability related to mineralogy derived from parent materials, as well as with cryogenic and soil processes affecting the depth distribution of the granulometric fractions and the organic matter. Navas et al. (2008) also analysed the soil characteristics in mudstones and volcanic rocks in Byers Peninsula, observing that the elemental composition was closely related to the mineralogy of parent materials. The spatial distribution of soils from the northern part of Byers Peninsula was recently described by
Moura et al. (2012). Their work proposed twenty different soil units, including Fluvisols, Regosols, Leptosols and Cryosols (according to the World Reference Base for Soil Resources), which correspond mostly to Fluvents, Orthents/Psamments, Inceptsols and Gelisols, respectively, according to the Soil Taxonomy. However, more information about the depth and spatial distribution of permafrost is necessary for a more conclusive classification of Cryosols or Gelisols.

\section{Palaeontology}

In Byers Peninsula, outcrops of sedimentary rocks are small and widely scattered but have provided much palaeontological information. The high value of this area has been highlighted by many authors, e.g. Hernández \& Azcárte (1971), Smellie et al. (1980), Crame (1984, 1995), Crame et al. (1993), Crame \& Kelly (1995), Hathway \& Lomas (1998). Following these studies, this area was found to have one of the most complete records of the JurassicEarly Cretaceous period in the northern part of the Pacific flank of the magmatic arc complex, being a key succession for the study of marine molluscan faunas and non-marine floras. The exposed Jurassic and Cretaceous sedimentary and fossiliferous strata on Byers Peninsula also have an outstanding scientific value for study of the former link between Antarctica and other southern continents. Particularly fruitful has been the Cerro Negro Formation from where important plant megafossils, corresponding to the Lower Cretaceous age, have been found. Some general works initiated the palaeofloristic knowledge of this rich site (Hernández \& Azcárate 1971, Torres et al. 1982, Césari et al. 1999), while more recent ones have centred on single finds or on palaeoecological interpretations. Byers Peninsula has led to the description of diverse, previously unknown, gymnosperms (Césari et al. 1998, Falcon-Lang \& Cantrill 2001), ferns (Césari 2006, Vera 2007, 2009, 2010, 2012), and even bryophytes (Vera 2011). Simultaneously, the data obtained have allowed reconstructions of the South Shetlands Early Cretaceous palaeovegetation (Falcon-Lang \& Cantrill 2002a, 2002b), and are relevant for the knowledge of the Mesozoic changes of vegetation in Antarctica (Orlando 1968, Cantrill \& Poole 2005).

Complementary information has been obtained from palynological studies based on fossil palynomorphs, including spores, pollen, and fossil microplankton (dinoflagellate cysts). From these sources new data are available, and have allowed environmental reconstructions and established floristic links with other parts of Gondwana. Palaeopalynology studies from Byers Peninsula have not only generated data on the Cerro Negro Formation Aptian age (Hathway et al. 1999), but also the larger and possibly more interesting Late Jurassic-Early Cretaceous interval (Askin 1981, 1983, Duane 1994, 1996, 1997). 


\section{Limnology and microbiology}

Byers Peninsula includes a high number of water bodies and can be considered one of the most useful sites for limnology in the Maritime Antarctic. However, these nonmarine aquatic ecosystems were not investigated until the late 1980s. The importance of environmental variables for species composition and abundance of periphytic diatoms was assessed by Hansson \& Håkansson (1992) using data from 21 lakes, including some on Byers Peninsula. But the first local and purely limnological publications were contributed by Davey (1993a, 1993b), describing the dynamics of some streams and ponds from Byers Peninsula for the first time, and by Jones et al. (1993) who correlated the water chemistry with diatom diversity in freshwaters ecosystems of Byers Peninsula. A multidisciplinary expedition in 1990-91 allowed the preparation of a general description of freshwater ecosystems by EllisEvans (1996). In 2001 the Limnopolar Programme started with a multidisciplinary perspective, based on the ecology of freshwater ecosystems from Byers Peninsula. Over a ten year period, the different ecosystems were described in detail and numerous experimental methods provided new and interesting results, predominantly concerning limnology. Examples of these results can be found in Toro et al. (2007), which includes the most detailed information on numerous water bodies in the peninsula, and Lyons et al. (2013), who described the geochemistry of several streams from Byers Peninsula. During the development of the project different organizational levels were explored, from viral and bacterioplankton communities (López-Bueno et al. 2009, Schiaffino et al. 2011, Villaescusa et al. 2013) to ecological dynamics (Camacho 2006, Villaescusa et al. 2010, Pla-Rabes et al. 2013). A large variety of new aquatic species were found, as well as a huge viral and ciliate diversity (Petz et al. 2007, López-Bueno et al. 2009), some new invertebrate species including oligochaetes (Rodriguez \& Rico 2008), and an increased number of diatom species (Van de Vijver et al. 2009, 2011, Zidarova et al. 2010, 2012, Kopalová \& Van de Vijver 2013). Agius et al. (2009) also confirmed that the winged Antarctic midge Parochlus steinenii (Gerke) was not a recent introduction to the Antarctic Peninsula region, and new diagnostic DNA techniques were developed by Bissett et al. (2005) with samples from Limnopolar Lake. These works culminated with the International Polar Year, with Byers Peninsula subject to an international and multidisciplinary research season in which more than 30 scientists participated with the aim of designating Byers Peninsula as an International Site of Reference for ecological studies. This successful project provided the tools and information for carrying out integration studies, such as the one from Velázquez et al. (2013) in which vegetation, geochemistry and limnology in the watershed were considered together. In recent years, all the knowledge regarding the structure, functioning and biotic interactions in Byers Peninsula aquatic ecosystems have been widely described in several informative works and book chapters (Camacho \& Fernández-Valiente 2005, Petz et al. 2005, Quesada et al. 2006, Toro et al. 2008, Quesada et al. 2008, Vincent et al. 2008, Rochera et al. 2011, Pearce \& Laybourn-Parry 2012, Vincent \& Quesada 2012, Camacho et al. 2012).

Several nematophagous fungi have been described through the analysis of soil samples from Byers Peninsula in areas occupied by Deschampsia antarctica Desv., Colobanthus quitensis (Kunth) Bartl. and the moss Sanionia uncinata (Hedw.) Loeske (Gray \& Smith 1984, Bonner \& Lewis Smith 1985). Microbial biodiversity in water bodies was analysed by López-Bueno et al. (2009), describing the largest viral genetic diversity found in any Antarctic lakes. The association between the ericoid mycorrhizal fungus Rhizoscyphus ericae (Read) Zhuang \& Korf. and the Antarctic leafy liverwort Cephaloziella varians (Gottsche) Steph. was studied by Upson et al. (2007) using material from Byers Peninsula, among other sites across a $1875 \mathrm{~km}$ transect through sub- and Maritime Antarctica. These authors also analysed root-fungal associations of Colobanthus quitensis and Deschampsia antarctica in another $1480 \mathrm{~km}$ latitudinal transect from South Georgia $\left(54^{\circ} \mathrm{S}, 36^{\circ} \mathrm{W}\right)$ through to the Léonie Islands on the western Antarctic Peninsula $\left(67^{\circ} \mathrm{S}, 68^{\circ} \mathrm{W}\right)$, again working with samples from Byers Peninsula. Rhizobia strains in cryospheric habitats were analysed by Nakai et al. (2013). In recent years, microbial mats have received significant attention from the scientific community. They constitute the dominant biomass in ice-free surfaces on Byers Peninsula. Numerous projects have been initiated to investigate several issues related to these multi-layered sheets of micro-organisms, including their dynamics (Velázquez et al. 2011), physiology and composition (Fernández-Valiente et al. 2007, Rochera et al. 2013a, 2013b) as well as their cold adaptation (Velázquez et al. 2011, Kleinteich et al. 2012).

\section{Terrestrial biodiversity}

As a major area within Maritime Antarctica that is ice-free in the summer and characterized by a relatively favourable climate, Byers Peninsula has both varied vegetation and a diverse flora. Nevertheless, the number of published studies based on the botany of this area is quite limited. The vegetation of Byers Peninsula is mainly known through the work of Lindsay (1971b), who used observations at this location to characterize typical vegetation types for the whole South Shetland Islands. Most of the 20 cryptogamic and three phanerogamic or bryophanerogamic assemblages described by Lindsay (1971b) occur on Byers Peninsula, although no detailed information about their distribution is available. Nevertheless, there is 
substantial floristic knowledge of different plant groups from the Peninsula. The two Antarctic native phanerogams are present there (Lindsay 1971b) and their distribution and reproductive capacity have now been assessed (Vera 2013). Particularly comprehensive data have been collected on the bryophytes of Byers Peninsula. The monumental work of Ochyra et al. (2008) includes references for 42 species of mosses, 17 of which are only known from Byers Peninsula within the relatively well-studied Livingston Island. Pertierra et al. (2013b) provided two additional records of mosses, one of them a novelty for the island, the other previously unknown in the South Shetlands. Moreover, BednarekOchyra et al. (2000) compiled the records of liverworts and reported six species from Byers Peninsula. Information on the lichen flora of Byers Peninsula is found in several publications (e.g. Lindsay 1969a, 1969b, 1971a, 1973, Lewis Smith \& Øvstedal 1991, Sancho et al. 1992, Matzer et al. 1994, Wirtz et al. 2003), but at least 56 lichen species are certainly known from Byers Peninsula (ATCM 2011). Casanovas et al. (2012) used data from a wide variety of Antarctic sites, including Byers Peninsula, to develop a multi-scale analysis of moss and lichen richness patterns on the Antarctic Peninsula. Finally, when considering the non-marine microalgae, the information on the terrestrial diatom flora of Byers Peninsula is particularly outstanding (Zidarova et al. 2010, Van de Vijver \& Zidarova 2011, Kopalová \& Van de Vijver 2013). Lewis Smith (1985) also reported the occurrence of several driftwood specimens on Byers Peninsula, predominantly of southern South American provenance, which could be serving as possible agents of biological immigration and colonization.

Richard et al. (1994) reported the first detailed study of the terrestrial invertebrate fauna of the Byers Peninsula using samples from a wide range of terrestrial and freshwater habitats, although earlier reports described the insects on Byers Peninsula (e.g. Greene et al. 1967, Bonner \& Lewis Smith 1985, Edwards \& Usher 1985). Fourteen micro-arthropod taxa (ten Acari and four Collembola) and two chironomid midges (Diptera) were recorded by Richard et al. (1994). Convey et al. (1996) revised this, adding a new species of springtail. A molecular clock approach to dating the presence of the Antarctic chironomid midges was employed by Allegrucci et al. (2006). This study included material from Byers Peninsula, and proposed the separation of those populations in the South Shetland Islands from others in Patagonia and sub-Antarctic South Georgia between 49 and 68.5 million years BP, depending on the species. Tardigrade eggs recovered from Limnopolar Lake were used by Gibson et al. (2007) to assess post-glacial colonization and Holocene tardigrade dynamics on the Southern Continent. Results suggested a slow colonization from Antarctic sources rather than wind transport from extra-continental sites. Rodríguez \& Rico (2008) described the new enchytraeid species Lumbricillus healyae Rodriguez \& Rico from freshwater streams situated in Byers Peninsula.
Nielsen et al. (2011) recorded 37 nematode taxa in soil samples from this site, and proposed that the location be considered a nematode biodiversity hotspot. Their results indicated that abiotic factors influence nematode communities with little evidence of biotic interactions. Allegrucci et al. (2012) used samples from Byers Peninsula to analyse the molecular relationships between three species of chironomid midges: Belgica antarctica Jacobs, Belgica albipes Séguy and Eretmoptera murphyi Schaeffer. More recently, Rico \& Quesada (2013) analysed natural drift patterns of Chironomidae populations in freshwater habitats of Maritime Antarctica, including data from within Byers Peninsula.

In the case of vertebrate fauna Byers Peninsula was extensively used for sealing in the first decades of 19th century. The sealing activity reduced the populations in the region enormously, to levels where seals were almost completely eradicated in some locations (Lewis Smith \& Simpson 1987). Once the sealing activity declined marine mammals populations recovered to some degree. The breeding marine fauna in Byes Peninsula is dominated by elephant seals (Mirounga leonina L.) that had a population of over 5000 individuals in 2011 which is two-fold higher than that found during the previous count in the 1960s (see Gil-Delgado et al. 2013, and references therein). Other abundant mammals include leopard seals (Hydrurga leptonyx Blainville) and Antarctic fur seals (Arctocephalus gazella Peters). Cryptosporidium and Giardia, two ubiquitous protozoan parasites which infect a wide variety of hosts, were analysed in faecal samples from different species of Antarctic pinnipeds by Rengifo-Herrera et al. (2011). These parasites were absent from Byers Peninsula samples.

The ornithofauna in Byers Peninsula is emblematic for this region and has been investigated by Gil-Delgado et al. (2013) who provided a new census of the dominant species: Antarctic tern (Sterna vittata Gmelin) with a population of about 3700 individuals, kelp gull (Larus dominicanus Lichtenstein) with a population of about 1900 individuals, giant petrel (Macronectes giganteus Gmelin) with 2800 individuals, and the Antarctic skua (Catharacta antarctica lonnbergi Mathews) with less than 100 birds in the area. The largest penguin colony is of gentoos (Pygoscelis papua Forster) with about 2400 individuals. The chinstrap penguin (Pygoscelis antarcticus Forster) are also present but with only 50 pairs. Other studies were performed on penguins, investigating the effects of tourism on the animals and using the Byers Peninsula colony as the control which experienced almost no human impact (Barbosa et al. 2013). Also, the presence of pathogenic bacteria has been investigated in the Byers Peninsula bird communities (Abad et al. 2013). Emslie et al. (2011) studied an abandoned penguin colony on Byers Peninsula and used radiocarbon dating to obtain an age of 285-480 yr вP for the last occupation of the site, although the authors estimated that penguin occupation lagged 
behind deglaciation by over 2000 years. Recently, Emslie et al. (2013) have applied a stable isotope analysis to ancient and modern gentoo penguin egg membranes to assess the krill surplus hypothesis in Antarctica, and obtained results that support this theory.

\section{Human dimension}

Byers Peninsula was one of the first sites in Antarctica to be occupied, and consequently has experienced almost two
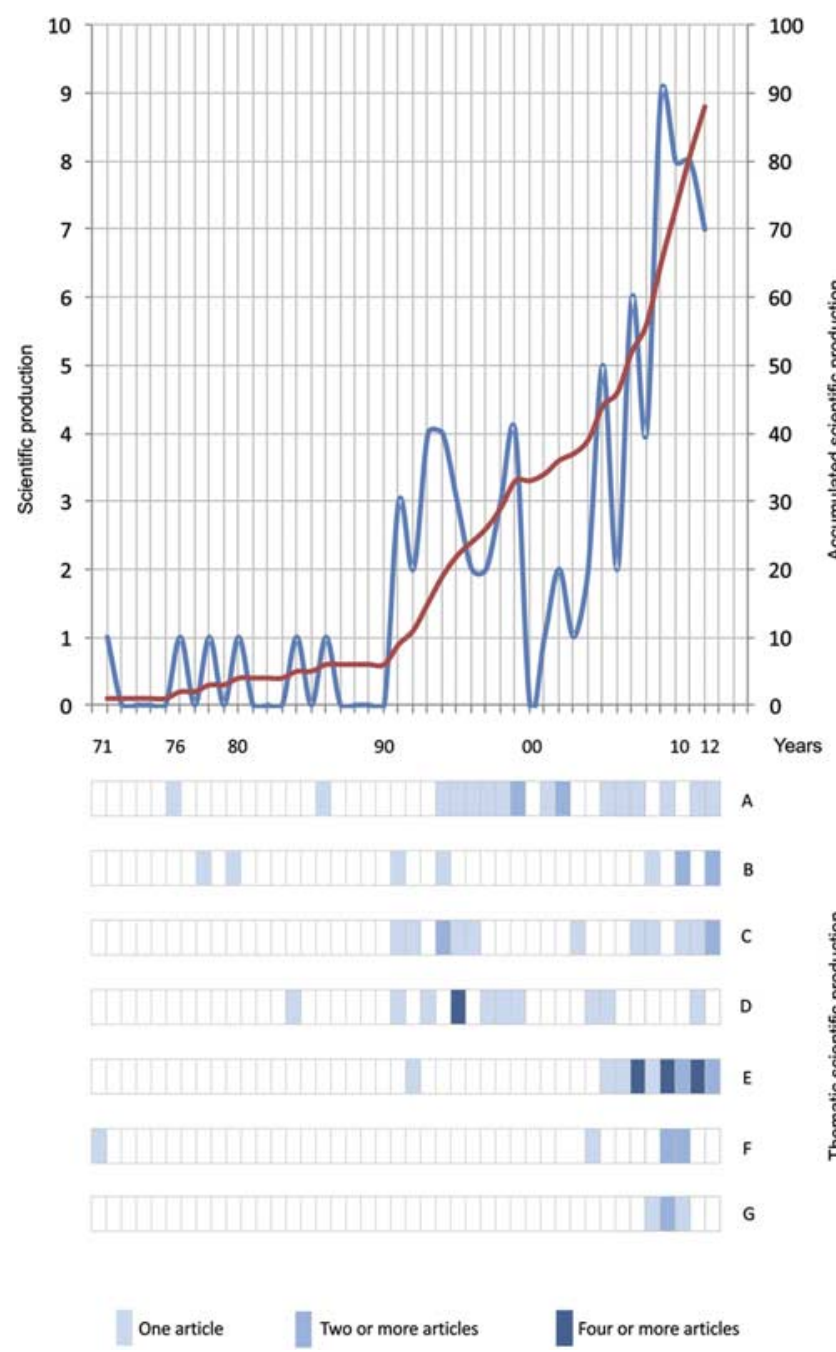

Fig. 1. Scientific paper publication over time resulting from research on Byers Peninsula (1971-2012). Blue line indicates the number of publications produced each year (left axis). Red line indicates the accumulated publications through time (right axis). A: Palaeontology, B: Geomorphology and Soils, C: Terrestrial Biodiversity, D: Geology and Stratigraphy, E: Limnology and Microbiology, F: Glaciology, Meteorology and Climate, and G: Human Dimension. Each bar represents a one year period. The number of publications per year is represented in three categories indicated by three colour intensities. This research incorporated only publications that appeared in Journal Citation Reports. centuries of intermittent human presence. Thus, science is not the only discipline studied on Byers; sealers' refuges and artefacts from the early 19th century have also been a source of extensive archaeological research (Lewis Smith \& Simpson 1987, Zarankin \& Senatore 2005, Pearson et al. 2008, 2010, Stehberg 2008, Stehberg et al. 2009). More than twenty refuges are documented in the area; some of them remain relatively well preserved with visible stone walls and small quantities of waste, such as glass bottle fragments. Early inhabitants of the South Shetland Islands have also left marine debris. Wood from sunken sailing boats has been found on Byers Peninsula and large quantities of debris can be found in the President and Robbery beaches as well as in coastal lakes (Harris 2001, Pertierra unpublished results). Also, pelagic plastics from different marine sources have been found on Byers Peninsula (Gregory \& Ryan 1997, ATCM 2011). The origins of this debris is not fully known; however, the type and quantity of waste recorded suggested that little can be linked with existing or abandoned field camps.

Recently, the research and logistic activities conducted in the former Spanish camp, now the Byers international camp, have been subject to retrospective impact assessments (Pertierra et al. 2013a). Byers international camp site has served as a case study for soil and vegetation trampling monitoring at remote scientific field camps in ASPAs. As a result a range of trampling strategies have been published (Tejedo et al. 2005, 2009, in press, Pertierra et al. 2013b). Doran \& Vincent (2012) included Byers Peninsula in a list of protected subglacial aquatic environments, describing a

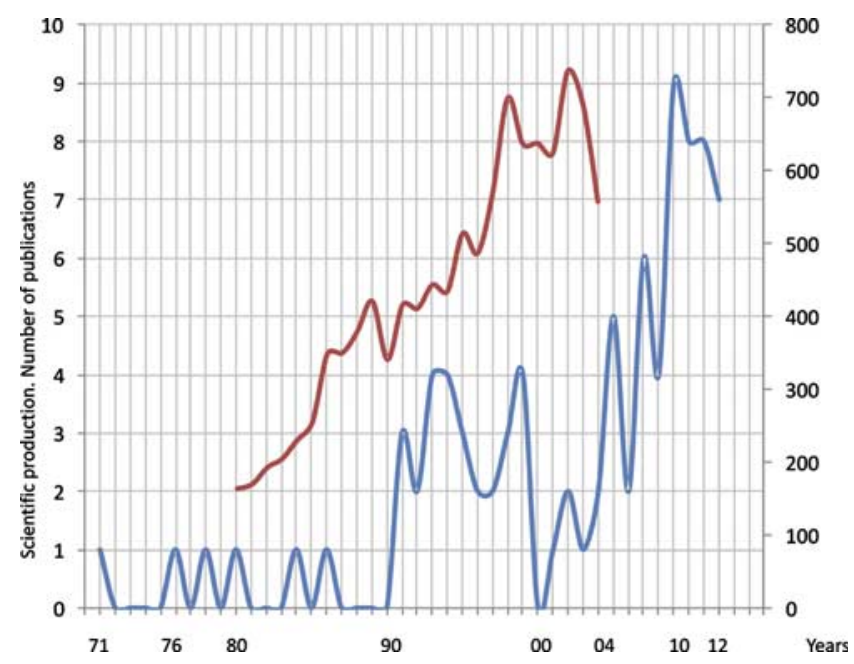

Fig. 2. Comparison of the level of scientific paper publication over time resulting from research in Byers Peninsula and Antarctica as a whole. The red line shows the number of scientific paper produced each year concerning the whole of Antarctic science (Dastidar 2007) (right axis). In comparison the blue line indicates the number of publications produced each year on science performed within Byers Peninsula (left axis). 

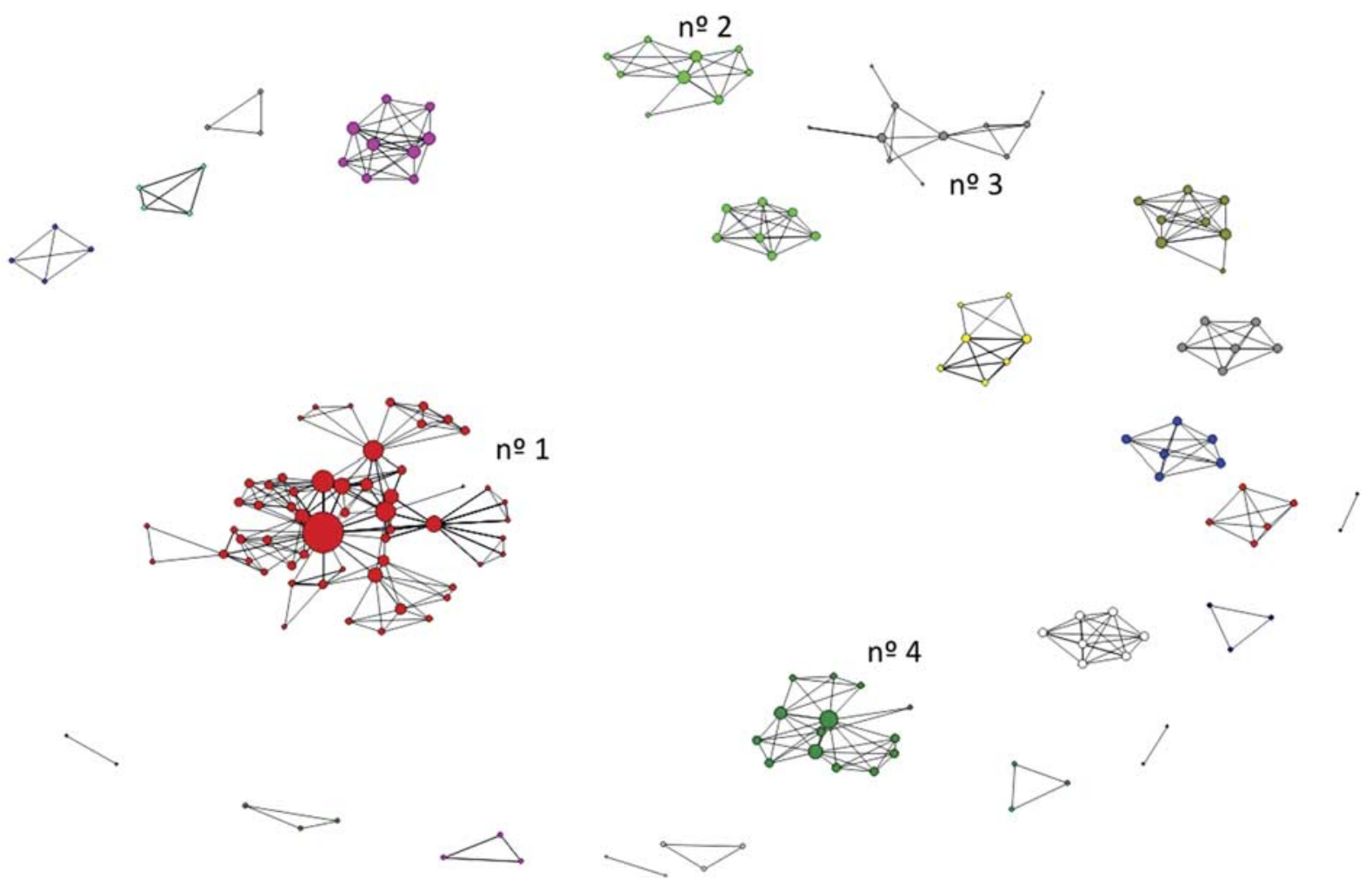

Fig. 3. Co-authorship social network. This figure attempts to show the level of interaction between researchers. Every node represents a single researcher, the size of the nodes indicates the number of publications by each author (degree). The lines show the relationships between the authors in the different publications (links).

Code of Conduct for the exploration of these environments formulated by a Scientific Committee on Antarctic Research Action Group. Finally the site has been used to assess the influence of field camps on the occurrence of organic pollutants in Antarctic soils and vegetation (Cabrerizo et al. 2012).

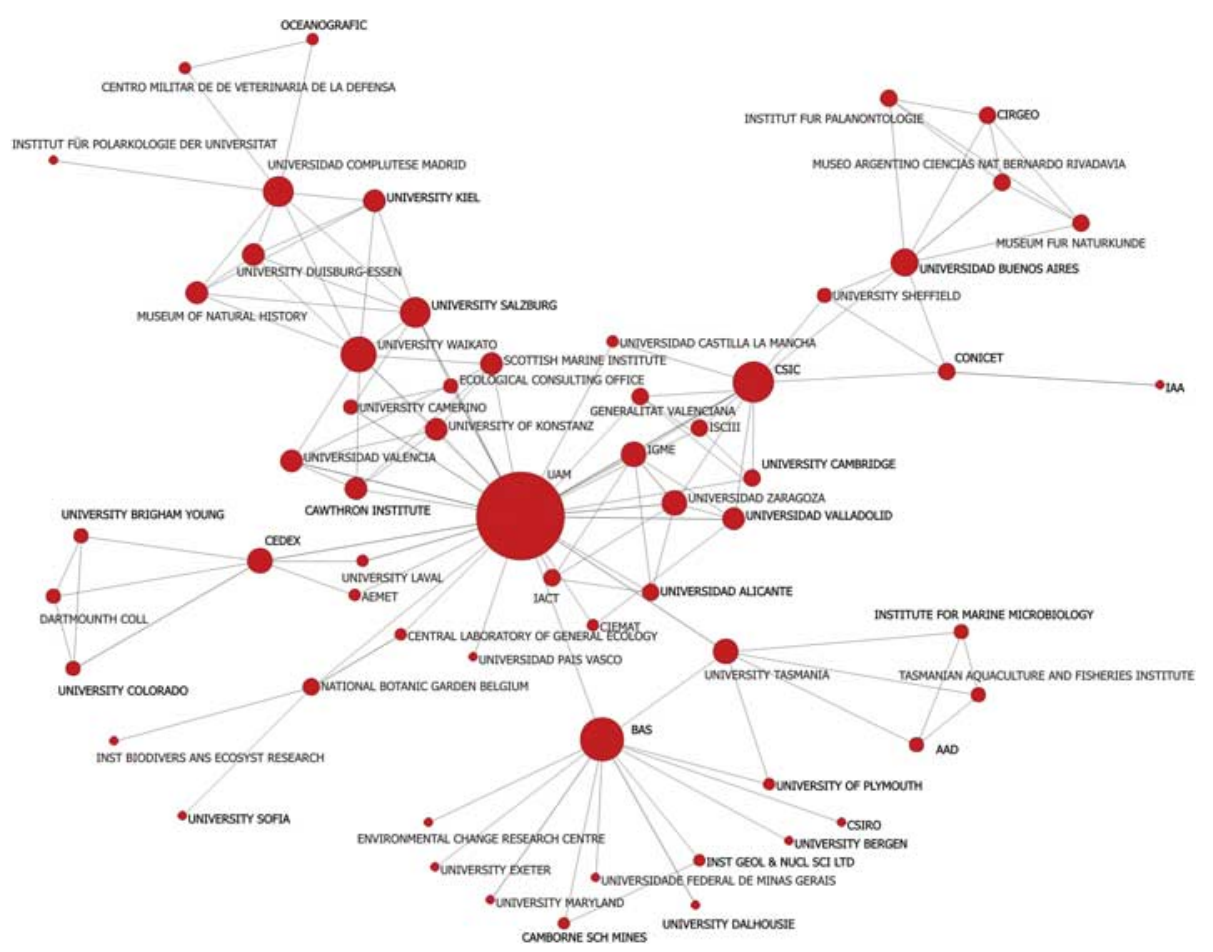

Fig. 4. Institutions participating in the publication of scientific research on Byers Peninsula. The eleven nations that engage in international collaborations are represented by researchers from 61 institutions. Each node represents the institutions participating in the publications. The size of the dots depends on the number of publications and the lines represent the co-authorship between different institutions. 


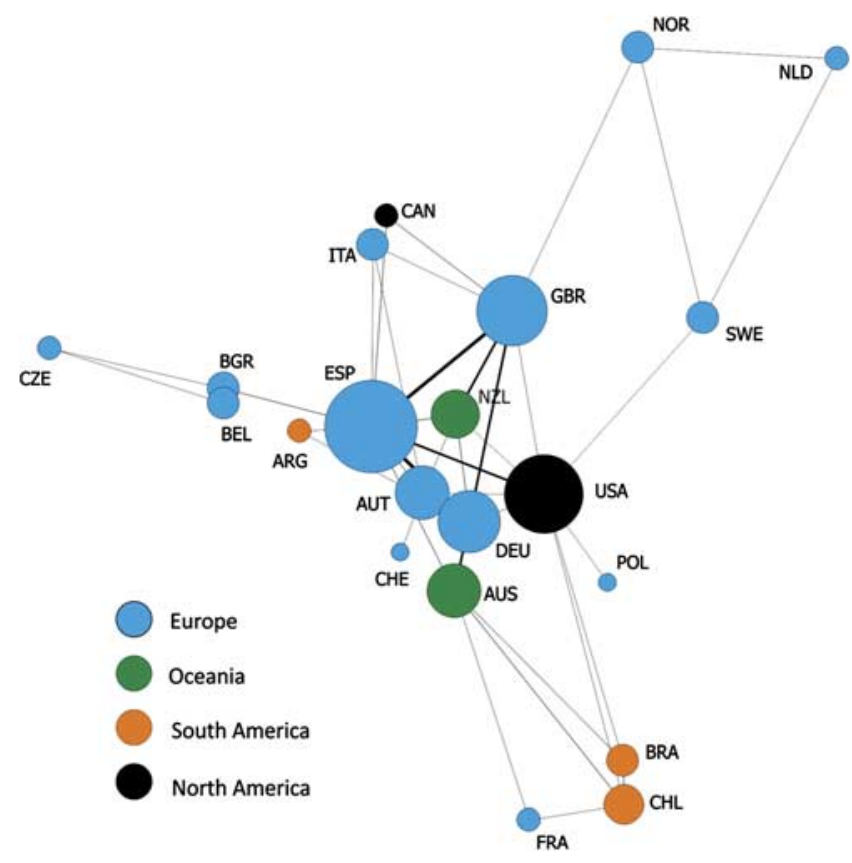

Fig. 5. Nations producing scientific publications based on research within Byers Peninsula. Each node represents the nationality of the institutions producing the scientific papers. The size of the nodes indicates the number of articles per nationality and the lines, the nationalities of the institutions sharing authorship of the articles.

\section{Bibliometric analysis}

We analysed scientific outputs by SCI from 1971 to early 2012. Around $93 \%$ of the articles have been published in the last 22 years (1990-2012) (Fig. 1). The curve of scientific productivity showed a positive trend, similar to the trend for Antarctica publications as a whole for the period 1980-2004 (Dastidar 2007) (Fig. 2).

The diversity of articles, classified by themes, was broad: Palaeontology (20\%), Microbiology and Limnology (24\%), Geology and Stratigraphy (19\%), Terrestrial Biodiversity (15\%), Geomorphology and Soil (10\%), Human Dimension (5\%) and Glaciology, Climate and Meteorology (7\%).

More than 200 authors have contributed to scientific research from Byers Peninsula (Fig. 3). In total 24 research groups were found with a minimum of two related authors and of these, 12 groups have five or more related authors. The rest are small independent research teams. In contrast, four aggregations contain nine or more related authors and three or more publications. These four clusters incorporate $44 \%$ of all authors and $54 \%$ of publications and are seen as big independent research consortia. In the main group, at the centre of Fig. 3, 58 authors are clustered. These authors belong to 110 institutions that have created a diffuse research network (Fig. 4). The node in the centre (Universidad Autónoma de Madrid, Spain) has the highest values for social connectivity (eigenvector) and has relationships with 45 of the 109 other institutions analysed (13 of which are Spanish).

The 110 institutions belong to 22 nations, all of which are signatories to the Antarctic Treaty. Of these nations, 21 have joint publications with scientist from other nations (Fig. 5). The country with scientific publications but no international authorship is South Africa (Hall 1994). More than half of the publications are from three countries: Spain (28\%), United Kingdom (18\%), and United States (9\%). In this analysis, Spanish institutions have collaborated to the largest extent, with research links with institutes in eleven different countries (Argentina, Canada, Belgium, Bulgaria, Italy, Austria, New Zealand, Germany, United States, Australia and United Kingdom). A high level of international cooperation can be seen in Byers Peninsula research, with $66 \%$ of the articles co-authored by researchers from two or more institutions from two or more countries.

\section{Discussion}

Byers Peninsula research: a hotspot of scientific values

Research on Byers Peninsula is of great interest to scientist from a diverse range of scientific disciplines. Hathway \& Lomas (1998) pointed out that the sedimentary and igneous outcrops constitute the best fossiliferous sequence for the Jurasic and Lower Cretaceous periods in the Pacific side of the Scotia Arc complex. These outcrops give highly valuable information for both geology and stratigraphy, and for the palaeontologic registry of marine molluscs and non-marine palaeobotany from these periods. Moreover, this area may have the most complete limnetic system in this region of the maritime Antarctic, with more than 60 lakes, freshwater pools and a dense network of temporary streams which are dependent upon seasonal snowmelt. The sediments within lake systems provide an essential archive for the study of the Holocene palaeoenvironment in the Antarctic Peninsula. From a biodiversity point of view, Byers Peninsula is considered a hotspot for Antarctica, with numerous species of different biological groups.

Research into all of these values has and will continue to require the presence within the ASPA of scientists from a wide range of scientific disciplines, including ornithology, entomology, botany, limnology, microbiology, geomorphology, geology and conservation biology. More recently, the development of increasingly sophisticated metagenomic techniques, which can now be incorporated readily into field research, has brought scientists from a new range of molecular biological disciplines into Byers Peninsula (e.g. López-Bueno et al. 2009). Multidisciplinary research often yields scientific insights of greater impact and value than science that focuses on only one discipline. Therefore, the presence of so many values of scientific interest within one area makes Byers Peninsula 
of immense value for research (Quesada et al. 2009), particularly as Antarctica continues to change. Furthermore, the long history of research in the area also makes it of potential value for the study of climate change impacts on terrestrial and lacustrine habitats and across a range of biological groups.

Nonetheless, the research lines conducted in Byers Peninsula have varied considerably since the original designation of the site as an SPA in 1966. Often the number of publications in certain disciplines are focussed around specific time periods (Fig. 1). This can be explained by the development of specific projects, for instance the production of publications concerning limnological studies has been mostly associated with the Limnopolar expeditions from 2001-10. On the other hand, periods of multidisciplinary scientific production in Byers Peninsula can be partially related to special events, such the International Expedition during the 1990-91 season. However, the rate of scientific production has been relatively consistent in the cases of palaeontology and, to a lesser degree, in geomorphology. It is also important to highlight the development of other areas such biological conservation in more recent years. Finally, when we compared levels of publication resulting from Byers Peninsula research with publications concerning Antarctica as a whole, we found a strong correlation (Fig. 2). The similar patterns may also reflect the participation in international events within Antarctica, such as the International Polar Year (IPY) during the 2008-09 season.

The social network analysis revealed the existence of different research groups in the scientific history of Byers Peninsula (Fig. 3). Up to 24 consortia were found to be present in the past or still active in research in the area with four dominant associations. When we examine the institutional network, we find a high level of relationship complexity (Fig. 4) involving institutes in 22 nations (Fig. 5). The proportion of Byers Peninsula publications co-written by contributors from different countries $(66 \%)$ is much higher than that identified by Dastidar (2007) for all the scientific publications of Antarctica (34.42\% in 2004). As shown by Bartneck \& Hu (2010) higher levels of collaboration in multidisciplinary fields increased the scientific outputs associated with each investigation. This is especially relevant in Antarctica where every field activity, inevitably, has some environmental cost. Thus, it is crucial that all results obtained on Byers Peninsula be published to avoid repetition and reduce the possibility of unnecessary reiterative visits, since human presence will always represent an impact in this almost pristine region.

\section{Environmental management of Byers Peninsula}

The current Byers Peninsula ASPA management plan attempts to take into consideration the needs and interests of the numerous scientific disciplines working in the area, the overarching requirement to protect natural values of this site, and the requirements of each Party operating within the ASPA boundary. Specifically, the management plan aims to i) avoid degradation of, or substantial risk to, the values of the area by preventing unnecessary human disturbance, ii) allow scientific research on the terrestrial and lacustrine ecosystems, marine mammals, avifauna, coastal ecosystems and geology, iii) allow other scientific research within the area provided it is for compelling reasons which cannot be served elsewhere, iv) allow archaeological research and measures for artefact protection, while protecting historic artefacts present within this site from unnecessary destruction, disturbance, or removal, v) prevent or minimize the introduction to the area of alien plants, animals and microbes, vi) minimize the possibility of the introduction of pathogens which may cause disease in fauna within the ASPA, and vii) allow visits for management purposes in support of the aims of the management plan. A balance has been found that attempts to accommodate all of these aims, and the management plan details a range of conditions that must be met before permits should be granted for entry to the area. Many of the conditions (e.g. disposal of waste, sampling of materials, installation of equipment and structures) are common to other ASPA management plans. However, there have been some new initiatives that apply specifically to Byers Peninsula. In 2011, the management plan underwent a major revision and an international field camp was designated $\left(62^{\circ} 34^{\prime} 35^{\prime \prime} \mathrm{S}, 61^{\circ} 13^{\prime} 07^{\prime \prime} \mathrm{W}\right)$, so that camping impacts are focused at one location, and two restricted zones were designated to protect the relatively pristine nature and scientific importance for microbiology of parts of the ASPA. In an attempt to preventing microbial or other contamination by human activity, those with permits to enter the restricted zones must wear sterile protective over-clothing, and to the maximum extent practicable, use only previously sterilized general field equipment and scientific equipment. In addition, camping and helicopter landings are not permitted.

ASPA No. 126 Byers Peninsula is unique within the Antarctic Protected Area System in being the only ASPA with three proponent Parties (out of the 71 ASPAs, 68 have a single proponent, and only two have two proponent Parties). To some degree, this may reflect international interest in the area and the willingness for Parties to engage in its protection. Nevertheless, better co-operation and communication between Parties and researchers is necessary for the continued protection of the values found within the area. Tourists are not permitted in the area, but inevitably long-term scientific research and environmental management activities have lead to some minor levels of impact, for example, by the creation of a path to an intensely studied lake, the presence of unmarked scientific apparatus of unknown origin and the presence of evidence of past field camps. Added to this, we still have no clear 
data on the level of introductions of non-native macro- and microbiota to the area, or information on the past use of stable or radioisotopes for scientific purposes. Both issues are generic across Antarctica.

Looking forward the overall protection of the area would be enhanced by: 1) more input into the environmental management of the ASPA by the various Parties who operate in the area, 2) better use of the existing Antarctic Treaty information exchange and reporting systems regarding the nature and location of activities undertaken in the area, 3) better on-going cooperation between Parties in the provision of logistical support for those working in the area, and 4) better interaction between scientists to prevent repetition of research that has already been undertaken. The high geodiversity and biodiversity and low levels of perturbation that characterize Byers Peninsula could in future lead to enhanced levels of research at this site. However, bearing in mind the need to protect and conserve the area, Antarctic Treaty Parties should only grant permits for scientific research within the Byers Peninsula ASPA 'provided it is for compelling reasons which cannot be served elsewhere', as specified in the area management plan. Furthermore, only studies whose impacts have been assessed as less than minor or transitory, should normally be permitted, as described in Annex I of the Protocol on Environmental Protection to the Antarctic Treaty.

\section{Conclusions}

The literature concerning Byers Peninsula, described in this paper, reflects the wide diversity of disciplines involved in research within this area over the past five decades. It is in the interests of all nations and scientists that Byers Peninsula is conserved to the maximum degree possible, in order that this research may continue. The Antarctic Treaty System specifically encourages international cooperation between nations. Collaborations promote both enhanced productivity and permit coordination of different scientific and logistical activities, thereby avoiding duplicating efforts and minimizing unintentional impacts resulting from the scientific research. This work aimed to integrate the interdisciplinary scientific knowledge about Byers Peninsula in order to facilitate both future international cooperation and enhance the cooperative conservation of Byers Peninsula.

\section{Acknowledgements}

This is a contribution of three projects: LIMNOPOLAR, EVA-ANTARCTICA and MIDAH. It was supported by the Spanish Government (REN2000-0435-ANT, REN2002-11617-E, CGL2004-20451-E, CGL2005/06549/ 02/01-ANT, POL2006-06635, CGL2007-28761-E/ANT, CTM2009-06604-E and CTM2010-11613-E). This article was published thanks to the financial support given by the Ministerio de Ciencia e Innovación (Spain) with the grant ref. CTM2011-12973-E. The paper also contributes to the British Antarctic Survey Polar Science for Planet Earth (PSPE) Environment Office Long Term Monitoring and Survey project. Finally, we thank two anonymous reviewers for their useful comments.

\section{Supplemental material}

A supplemental table will be found at http://dx.doi.org/ $10.1017 / \mathrm{S} 0954102012001058$

\section{References}

Abad, F.X., Busquets, N., SÁnchez, A., Ryan, P.G., Majó, N. \& GonzÁlez-Solís, J. 2013. Serological and virological surveys of the influenza A viruses in Antarctic and sub-Antarctic penguins. Antarctic Science, 25, 10.1017/S0954102012001228.

Agius, J.T., Gibson, J.A.E., Rico, E. \& Quesada, A. 2009. Paleolimnological evidence confirms that Parochlus steinenii (Gerke) is not a recent introduction to the Antarctic Peninsula region. Chironomus, 2, 18-21.

Alfaro, P., López-Martínez, J., Maestro, A., Galindo-Zaldívar, J., Durán-VAlsero, J.J. \& CuChi, J.A. 2010. Recent tectonic and morphostructural evolution of Byers Peninsula (Antarctica): insight into the development of the South Shetland Islands and Bransfield Basin. Journal of Iberian Geology, 36, 21-37.

Allegrucci, G., Carchini, G., Convey, P. \& Sbodorni, V. 2012. Evolutionary geographic relationships among orthocladine chironomid midges from maritime Antarctic and sub-Antarctic islands. Biological Journal of the Linnean Society, 106, 258-274.

Allegrucci, G., Carchini, G., Tordisco, V., Convey, P. \& Sbordoni, V. 2006. A molecular phylogeny of Antarctic chironomidae and its implications for biogeographical history. Polar Biology, 29, 320-326.

ArayA, R. \& Hervé, F. 1972a. Patterned gravel beaches in South Shetlands. In AdIE, R.J., ed. Antarctic geology and geophysics. Oslo: International Union of Geological Science, 111-114.

Araya, R. \& Hervé, F. 1972b. Periglacial phenomena in the South Shetland Islands. In ADIE, R.J., ed. Antarctic geology and geophysics. Oslo: International Union of Geological Science, 105-109.

Arche, A., Martínez de Pisón, E. \& Serrano, E. 1994. Subaqueous sliding on Byers Peninsula. In Cacho, J. \& Serrat, D., eds. Actas del V Simposio Español de Estudios Antárticos. Madrid: Comisión Interministerial de Ciencia y Tecnología, 170-171.

Arche, A., Martínez de Pisón, E. \& Serrano, E. 1997. Sedimentos de plataforma continental dominada por el oleaje en la Formación Anchorage (Jurásico Superior), Península Byers, Isla Livingston. Boletín de la Real Sociedad Española de Historia Natural, Sección Geológica, 92, 175-180.

Arche, A., López-Martínez, J., Serrano, E. \& Martínez de Pisón, E. 1996. Marine landforms and deposits. In López-Martínez, J., Thomson, M.R.A. \& Thomson, J.W., eds. Geomorphological map of Byers Peninsula, Livingston Island. BAS GEOMAP Series, Sheet 5-A, Scale 1:25 000. Cambridge: British Antarctic Survey, 35-42.

Askin, R.A. 1981. Jurassic-Cretaceous palynology of Byers Peninsula, Livingston Island, Antarctica. Antarctic Journal of the United States, 16(5), 11-13.

Askin, R. 1983. Tithonian (Uppermost Jurassic)-Barremian (Lower Cretaceus) spores, pollen and microplankton from the South Shetland Islands, Antarctica. In Oliver, R.L., James, P.R. \& JAGO, J.B., eds. Antarctic earth science. Cambridge: Cambridge University Press, 295-297. 
Atcm (Antarctic Treaty Consultative Meeting). 2011. Management Plan for Antarctic Specially Protected Area No. 126 Byers Peninsula, Livingston Island, South Shetland Islands. Measure 4, XXXIV Antarctic Treaty Consultative Meeting, Buenos Aires, June 2011, 23 pp.

BAÑón, M. 2004. Introducción al clima de la Península Byers, Isla Livingston, Antártida. Comparación con la BAE Juan Carlos I. MSc thesis. Instituto Universitario de Geografía, Universidad de Alicante, Spain, 112 pp. [Unpublished].

Bañón, M., Justel, M.A. \& Quesada, A. 2006. Análisis del topoclima y microclima de la isla Livingston, Antártida, en el marco del proyecto LIMNOPOLAR. In XXIX Jornadas Cientificas de la AME. Aplicaciones meteorológicas. Madrid: Asociación Meteorológica Española.

Bañón, M., Justel, A., Velázquez, D. \& Quesada, A. 2013. Regional weather survey on Byers Peninsula, Livingston Island, South Shetland Islands, Antarctica. Antarctic Science, 25, 10.1017/S0954102012001046.

Barbosa, A., de Mas, E., Benzal, J., Diaz, J.I., Motas, M., Jerez, S., Pertierra, L., Benayas, J., Justel, A., Lauzurica, P., Garciapeña, F.J. \& Serrano, T. 2013. Pollution and physiological variability in gentoo penguins at two rookeries with different levels of human visitation. Antarctic Science, 25, 10.1017/S0954102012000739.

Bartneck, C. \& Hu, J. 2010. The fruits of collaboration in a multidisciplinary field. Scientometrics, $85,41-52$.

Bednarek-Ochyra, H., Váña, J., Ochyra, R. \& Smith, R.I.L. 2000. The liverwort flora of Antarctica. Cracow: Polish Academy of Sciences, $236 \mathrm{pp}$.

BiRniE, R.V. \& GoRDon, J.E. 1980. Drainage systems associated with snow melt, South Shetland Islands, Antarctica. Geografiska Annaler, 62A, 57-62.

Bissett, A., Gibson, J.A.E., Jarman, S.N., Swadling, K.M. \& Cromer, L. 2005. Isolation, amplification, and identification of ancient copepod DNA from lake sediments. Limnology and Oceanography, 3, 533-542.

BJörCK, S. \& ZALE, R. 1996. Late Holocene tephrochronology and palaeoclimate, based on lake sediment studies. In LóPEZ-MARTínEZ, J., Thomson, M.R.A. \& THомson, J.W., eds. Geomorphological map of Byers Peninsula, Livingston Island. BAS GEOMAP Series, Sheet 5-A, Scale 1:25 000. Cambridge: British Antarctic Survey, 43-48.

Buörck, S., SANDgren, P. \& ZaLe, R. 1991c. Late Holocene tephrochronology of the northern Antarctic Peninsula. Quaternary Research, 36, 322-328.

BJörCK, S., HJort, C., IngOlfsson, O. \& SKOG, R. 1991b. Radiocarbon dates from the Antarctic Peninsula Region: problems and potential. Quaternary Proceedings, 1, 55-65.

Buörck, S., Håkansson, H., Olsson, S., Barnekow, L. \& Janssens, J. 1993. Palaeoclimatic studies in South Shetland Islands, Antarctica, based on numerous stratigraphic variables in lake sediments. Journal of Paleolimnology, 8, 233-272.

Björck, S., Hakansson, H., Zale, R., Karlén, W. \& Jönsson, B.L. 1991a. A late Holocene lake sediment sequence from Livingston Island, South Shetland Islands, with palaeoclimatic implications. Antarctic Science, 3, 61-72.

BJörck, S., HJort, C., Ingolfsson, O., Zale, R. \& Ising, J. 1996. Holocene deglaciation chronology from lake sediments. In LÓPEZ-MARTínEZ, J., Thomson, M.R.A. \& Thomson, J.W., eds. Geomorphological map of Byers Peninsula, Livingston Island. BAS GEOMAP Series, Sheet 5-A, Scale 1:25 000. Cambridge: British Antarctic Survey, 49-51.

Bonner, W.N. \& Lewis Smith, R.I., eds. 1985. Conservation areas in the Antarctic. Cambridge: SCAR, 298 pp.

Cabaleri, N., Parica, C., Remesal, M., Salani, F. \& Valencio, S. 1997. The lava-sedimentary Mesozoic association of lacustrine environment of Byers Peninsula, South Shetland Islands. In RiccI, C.A., ed. The Antarctic Region: geological evolution and processes. Siena: Terra Antartica Publications, 361-366.

Cabrerizo, A., Dachs, J., Barceló, D. \& Jones, K.C. 2012. Influence of organic matter content and human activities on the occurrence of organic pollutants in Antarctic soils, lichens, grass, and mosses. Environmental Science \& Technology, 46, 1396-1405.
Calvet, J., Pallàs, R., Sàbat, F. \& Vilaplana, J.M. 1994. Dating ash-layers in glaciers of Livingston Island. In CACHO, J. \& Serrat, D., eds. Actas del V Simposio Español de Estudios Antárticos. Madrid: Comisión Interministerial de Ciencia y Tecnología, 195-208.

CAMAcho, A. 2006. Planktonic microbial assemblages and the potential effects of metazooplankton predation on the food web of lakes from the maritime Antarctica and sub-Antarctic islands. Reviews in Environmental Science and Bio/Technology, 5, 167-185.

Camacho, A. \& Fernández-Valiente, E. 2005. Un mundo dominado por los microorganismos: ecología microbiana de los lagos antárticos. Ecosistemas, 14, 66-78.

Camacho, A., Rochera, C., Villaescusa, J.A., Velázquez, D., Toro, M., Rico, E., Fernández-Valiente, E., Justel, A., Bañón, M. \& Quesada, A. 2012. Maritime Antarctic lakes as sentinels of climate change. International Journal of Design \& Nature and Ecodynamics, 7, 239-250.

Cantrill, D.J. \& Poole, I. 2005. Taxonomic turnover and abundance in Cretaceous to Tertiary wood floras of Antarctica: implications for changes in forest ecology. Palaeogeography, Palaeoclimatology, Palaeoecology, 215, 205-219.

Casanovas, P., Lynch, H. \& Fagan, W.F. 2012. Multi-scale patterns of moss and lichen richness on the Antarctic Peninsula. Ecography, 10.1111/j.1600-0587.2012.07549.x.

CÉSARI, S.N. 2006. Aptian ferns with in situ spores from the South Shetland Islands, Antarctica. Review of Palaeobotany and Palynology, 138, 227-238.

Césari, S.N., Parica, C., Remesal, M. \& Salani, F. 1998. First evidence of Pentoxylales in Antarctica. Cretaceous Research, 19, 733-743.

Césari, S.N., Parica, C., Remesal, M. \& Salani, F. 1999. Paleofloras del cretácico inferior de Península Byers, Isla Livingston, Antártida. Ameghiniana, 36, 3-22.

Convey, P., Greenslade, P., Richard, K.J. \& Block, W. 1996. The terrestrial arthropod fauna of the Byers Peninsula, Livingston Island, South Shetland Islands: Collembola. Polar Biology, 16, 257-259.

Covacevich, V. 1976. Fauna Valanginiana de Peninsula Byers, Isla Livingston, Antarctica. Revista Geológica de Chile, 3, 25-56.

CRAme, J.A. 1984. Preliminary bivalve zonation of the Jurassic-Cretaceous boundary in Antarctica. In Perrilliat, M.C., ed. Memoria, III Congreso Latinamerico de Paleontologia. México, DF: Universidad Nacional Autónoma de Mexico, Instituto de Geología, 242-254.

Crame, J.A. 1995. A new Oxytomid bivalve from the Upper Jurassic-Lower Cretaceous of Antarctica. Palaeontology, 39, 615-628.

Crame, J.A. \& Kelly, S.R.A. 1995. Composition and distribution of the inoceramid bivalve genus Anopaea. Palaeontology, 38, 87-103.

Crame, J.A., Pirrie, D., Crampton, J.S. \& Duane, A.M. 1993. Stratigraphy and regional significance of the Upper Jurassic-Lower Cretaceous Byers Group, Livingston Island, Antarctica. Journal of the Geological Society of London, 150, 1075-1087.

Cross, R., Borgatti, S.P. \& Parker, A. 2002. Making invisible work visible: using social network analysis to support strategic collaboration. California Management Review, 44, 25-46.

Cuchí, J.A., Durán, J.J., Alfaro, P., Serrano, E. \& López-Martínez, J. 2004. Discriminant physicochemical properties of various waters in a permafrost area of the Byers Peninsula (Livingston Island, western Antarctica). Boletín de la Real Sociedad Española de Historia Natural, Sección Geologica, 99, 75-82.

CuRL, J.E. 1980. A glacial history of the South Shetland Islands, Antarctica. Columbus, OH: The Ohio State University, Institute of Polar Studies, Report 63, 168-176.

Dalziel, I.W.D., Price, D.P. \& Stirewalt, G.L. 1970. Structural studies in the Scotia Arc: Elephant Island, Gibbs Island, Hope Bay, and Livingston Island. Antarctic Journal of United States, 5(4), 100-101.

DAstidar, P.G. 2007. National and institutional productivity and collaboration in Antarctic science: an analysis of 25 years of journal publications. Polar Science, 26, 175-180.

DAVEY, M.C. 1993a. Carbon and nitrogen dynamics in a maritime Antarctic stream. Freshwater Biology, 30, 319-330. 
Davey, M.C. 1993b. Carbon and nitrogen dynamics in a small pond in the maritime Antarctic. Hydrobiologia, 257, 165-175.

De Pablo, M.A., Ramos, M., Vieira, G. \& Quesada, A. 2010. A new CALM-S site on Byers Peninsula, Livingston Island, Antarctica. In Blanco, J.J., De Pablo, M.A. \& Ramos, M., eds. Ambientes periglaciares, permafrost y variabilidad climática: II Congreso Ibérico de la International Permafrost Association. Alcalá de Henares: Servicio de Publicaciones de la Universidad de Alcalá, 153-159.

De Pablo, M.A., Blanco, J.J., Molina, A., Ramos, M., Vieira, G. \& QuesaDA, A. 2013. Interannual active layer variability at the Limnopolar Lake CALM Site, Byers Peninsula, Livingston Island, Antarctica. Antarctic Science, 25, 10.1017/S0954102012000818.

Demant, A., Touron, S., Lapierre, H. \& Bosch, D. 2004. Cretaceous arc volcanism of Byers Peninsula, Livingston Island, Antarctica: new petrological, geochemical and isotope data. Bulletin de la Société Géologique de France, 175, 131-145.

Doran, P.T. \& Vincent, W.F. 2012. Environmental protection and stewardship of subglacial aquatic environments. Geophysical Monograph Series, 192, 149-157.

Duane, A.M. 1994. Preliminary palynological investigation of the Byers Group (Late Jurassic-Early Cretaceous), Livingston Island, Antarctic Peninsula. Review of Palaeobotany and Palynology, 84, 113-120.

Duane, A.M. 1996. Palynology of the Byers Groups (Late Jurassic-Early Cretaceous) of Livingston and Snow islands, Antarctic Peninsula: its biostratigraphical and palaeoenvironmental significance. Review of Palaeobotany and Palynology, 91, 241-281.

DuAne, A.M. 1997. Taxonomic investigations of palynomorphs from the Byers Group (Upper Jurassic-Lower Cretaceous), Livingston and Snow islands, Antarctic Peninsula. Palynology, 21, 123-144.

Edwards, M. \& Usher, M.B. 1985. The winged Antarctic midge Parochlus steineni (Gerke) (Diptera:Chironomidae) in the South Shetland Islands. Biological Journal of the Linnean Society, 26, 83-93.

Eluis-Evans, J.C. 1996. Biological and chemical features of lakes and streams. In López-Martínez, J., Thomson, M.R.A. \& Thomson, J.W., eds. Geomorphological map of Byers Peninsula, Livingston Island. BAS GEOMAP Series, Sheet 5-A, Scale 1:25 000. Cambridge: British Antarctic Survey, 20-22.

Emslie, S.D., Baumann, K. \& van Tuinen, M. 2011. Late Holocene occupation of gentoo penguins (Pygoscelis papua) on Byers Peninsula, Livingston Island, Antarctica. Polar Biology, 34, 283-290.

Emslie, S.D., Politto, M.J. \& Patteron, W.P. 2013. Stable isotope analysis of ancient and modern gentoo penguin egg membrane and the krill surplus hypothesis in Antarctica. Antarctic Science, 25, 10.1017/ S0954102012000740.

EVERETT, K.R. 1971. Observations on the glacial history of Livingston Island. Arctic, 24, 41-50.

Falcon-Lang, H.J. \& Cantrill, D.J. 2001. Gymnosperm woods from the Cretaceous (mid-Aptian) Cerro Negro Formation, Byers Peninsula, Livingston Island, Antarctica: the arborescent vegetation of a volcanic arc. Cretaceous Research, 22, 277-293.

FalCon-LANG, H.J. \& CANTRILL, D.J. 2002a. Terrestrial paleoecology of the Cretaceous (early Aptian) Cerro Negro Formation, South Shetlands Islands, Antarctica: a record of polar vegetation in a volcanic arc environment. Palaios, 17, 491-506.

FalCon-Lang, H.J. \& CANTRILL, D.J. 2002b. Terrestrial palaeoecology of an Early Cretaceous volcanic archipelago, Byers Peninsula and President Head, South Shetlands Islands, Antarctica. Palaios, 17, 535-549.

Fassnacht, S.R. \& Toro, M. 2013. Mapping snow cover and snow depth across the Lake Limnopolar watershed on Byers Peninsula, Livingston Island, Maritime Antarctica. Antarctic Science, 25, 10.1017/ S0954102012001216.

Fassnacht, S.R., Toro-Velasco, M., Meiman, P.J. \& Whitt, Z.C. 2010. The effect of aeolian deposition on the surface roughness of melting snow, Byers Peninsula, Antarctica. Hydrological Processes, 24, 2007-2013.
Fernández-Valiente, E., Camacho, A., Rochera, C., Rico, E., Vincente, W.F. \& QuesadA, A. 2007. Community structure and physiological characterization of microbial mats in Byers Peninsula, Livingston Island (South Shetland Islands, Antarctica). FEMS Microbiology Ecology, 59, 377-385.

FRANCIS, J.E. 1986. Growth rings in Cretaceous and Tertiary wood from Antarctica and their paleoclimatic implications. Palaeontology, 29, $665-684$.

Gibson, J.A.E., Cromer, L., Agius, J.T., McInnes, S.J. \& Marley, N.J. 2007. Tardigrade eggs and exuviae in Antarctic lake sediments: insights into Holocene dynamics and origins of the fauna. In Pilato, G. \& Rebecchi, L., eds. Proceedings of the Tenth International Symposium on Tardigrada. Journal of Limnology, 66(S1), 65-71.

Gil-Delgado, J.A., GonzÁlez-Solís, J. \& Barbosa, A. 2013. Populations of breeding birds in Byers Peninsula, Livingston Island, South Shetlands Islands. Antarctic Science, 25, 10.1017/S0954102012000752.

González-Casado, J.M., López-Martínez, J., Durán, J.J. \& Gergamín, J.F. 1997. Fracturación y campos de esfuerzos recientes en el entorno del Estrecho de Bransfield, Antártida Occidental. Boletín de la Real Sociedad Española de Historia Natural (Sección Geología), 93, 181-188.

González-Ferrán, O., Katsui, Y. \& Tavera, J. 1970. Contribución al conocimiento geológico de la Península Byers, Isla Livingston, Islas Shetland del Sur, Antártica. Instituto Antártico Chileno, Serie Cientifica, 1, 41-54.

Gracanin, T.M. 1983. Geochemistry and geochronology of some Mesozoic igneous rocks from the northern Antarctic Peninsula region. MSc thesis, Ohio State University, 386 pp. [Unpublished.]

Gray, N.F. \& SMITH, R.I.L. 1984. The distribution of nematophagous fungi in the maritime Antarctic. Mycopathologia, 85, 81-92.

Greene, S.W., Gressitt, J.L., Korb, D., Llano, G.A., Rudolph, E.D., Singer, R., Steere, W.C. \& Ugolini, F.C. 1967. Terrestrial life in Antarctica. Antarctic Map Folio Series, 5, 11 plates.

Gregory, M.R. \& Ryan, P.G. 1997. Pelagic plastics and other seaborne persistent synthetic debris: a review of Southern Hemisphere perspectives. In CoE, J.M. \& Rogers, D.B., eds. Marine debris: sources, impacts and solutions. New York: Springer, 49-66.

Grunow, A.M. 1993. New paleomagnetic data from the Antarctica Peninsula and their tectonic implications. Journal of Geophysical Research, 98, 13 815-13833.

Hall, B.L. 2003. An overview of late Pleistocene glaciation in the South Shetland Islands. Antarctic Research Series, 79, 103-113.

HaLL, B.L. 2010. Holocene relative sea-level changes and ice fluctuations in the South Shetland Islands. Global and Planetary Change, 74, 15-26.

Hall, B.L. \& Perry, E.R. 2004. Variations in ice-rafted detritus on beaches in the South Shetland Islands: a possible climate proxy. Antarctic Science, 16, 339-344.

HaLL, B.M. 2009. Holocene glacial history of Antarctica and sub-Antarctic Islands. Quaternary Science Reviews, 28, 2213-2230.

HaLl, K.J. 1992a. Mechanical weathering on Livingston Island, South Shetland Islands, Antarctica. In Yoshida, Y., Kaminuma, K. \& Shiraishi, $\mathrm{K}$., eds. Recent progress in Antarctic earth science. Tokyo: Terra Scientific Publishing Company, 757-762.

HaLL, K.J. 1992b. Mechanical weathering in the Antarctic: a maritime perspective. In Dixon, J.C. \& ABrahams, A.D., eds. Periglacial geomorphology. Chichester: Wiley, 103-123.

HALL, K.J. 1993a. Enhanced bedrock weathering in association with latelying snowpatches: evidence from Livingston Island, Antarctica. Earth Surface Processes and Landforms, 18, 121-129.

HaLL, K.J. 1993b. Rock temperatures from Livingston Island (maritime Antarctic): implications for cryogenic weathering. Permafrost Sixth International Conference, Proceedings. Beijing: South China University of Technology Press, 1, 220-225.

HaLl, K.J. 1994. Some observations regarding sorted stripes, Livingston Island, South Shetland. Permafrost and Periglacial Processes, 5, 119-126. 
Hansom, J.D. 1979. Radiocarbon dating of a raised beach at $10 \mathrm{~m}$ in the South Shetland Islands. British Antarctic Survey Bulletin, No. 49, 287-288.

Hansson, L.A. \& HÅKANSSON, H. 1992. Diatom community response along a productivity gradient of shallow Antarctic lakes. Polar Biology, 12, 463-468.

HARRIS, J.D. 2001. Radiocarbon dating of a raised beach at $10 \mathrm{~m}$ in the South Shetland Islands. British Antarctic Survey Bulletin, No. 49, 287-288.

Hathway, B. 1997. Non-marine sedimentation in an Early Cretaceous extensional continental-margin arc, Byers Peninsula, Livingston Island, South Shetland Islands. Journal of Sedimentary Research, 67, 686-697.

Hathway, B. \& Lomas, S.A. 1998. The Upper Jurassic-Lower Cretaceous Byers Peninsula Group, South Shetland Islands, Antarctica: revised stratigraphy and regional correlations. Cretaceous Research, 19, 43-67.

Hathway, B., Duane, A.M., Cantrill, D.J. \& Kelley, S.P. 1999. Ar-40/ Ar-39 geochronology and palynology of the Cerro Negro Formation, South Shetland Islands, Antarctica: a new radiometric tie for Cretaceous terrestrial biostratigraphy in the Southern Hemisphere. Australian Journal of Earth Sciences, 46, 593-606.

Henríquez, O.M. 1994. Soil characterization of the Byers Peninsula, Livingston Island, South Shetland Islands (Antarctic). PhD thesis, Universidad de Chile, Santiago, 102 pp. [Unpublished]

Hernández, P.J. \& Azcárate, V. 1971. Estudio paleobotánico preliminar sobre restos de una tafoflora de la Peninsula Byers (Cerro Negro), Isla Livingston, Islas Shetland del Sur, Antártica. Instituto Antártico Chileno, Serie. Cientifica, 2, 15-50.

Hernández-Cifuentes, F. 1994. Geodesy and topography of Livingston and Deception islands. In CAcho, J. \& Serrat, D., eds. Actas del V Simposio Español de Estudios Antárticos. Madrid: Comisión Interministerial de Ciencia y Tecnología, 291-302.

Hernández-Cifuentes, F., López-Martínez, J. \& Thomson, M.R.A. 1996. Topographic map. In López-Martínez, J., Thomson, M.R.A. \& Thomson, J.W., eds. Geomorphological map of Byers Peninsula, Livingston Island. BAS GEOMAP Series, Sheet 5-A, Scale 1:25 000. Cambridge: British Antarctic Survey, 5-8.

HJort, C., Ingolfsson, O. \& BJörcK, S. 1992. The last major deglaciation in the Antarctic Peninsula Region: a review of recent Swedish Quaternary research. In Yoshida, Y., Kaminuma, K. \& Shiraishi, K., eds. Recent progress in Antarctic earth science. Tokyo: Terra Scientific Publishing Company, 741-743.

Hobis, E.J. 1968. The geology of the South Shetland Islands, IV. The geology of Livingston Island. British Antarctic Survey Scientific Reports, No. 47, 34 pp.

Hodgson, D., Dyson, C.L., Jones, V.J. \& Smellie, J.L. 1998. Tephra analysis of sediments from Midge Lake (South Shetland Islands) and Sombre Lake (South Orkney Islands), Antarctica. Antarctic Science, 10, $13-20$.

Hughes, K.A. \& Convey, P. 2010. The protection of Antarctic terrestrial ecosystems from inter- and intra-continental transfer of non-indigenous species by human activities: a review of current systems and practices. Global Environmental Change, 20, 96-112.

John, B.S. \& Sugden, D.E. 1971. Raised marine features and phases of glaciation in the South Shetland Islands. British Antarctic Survey Bulletin, No. 24, 45-111.

Jones, V.J., Juggins, S. \& Ellins-Evans, J.C. 1993. The relationship between water chemistry and surface sediment diatom assemblages in maritime Antarctic lakes. Antarctic Science, 5, 339-348.

Kiessling, W., Scasso, R., Zeiss, A., Riccardi, A.C. \& Medina, F.A. 1999. Combined radiolarian-ammonite stratigraphy for the Late Jurassic of the Antarctic Peninsula: implications for radiolarian stratigraphy. Geodiversitas, 21, 687-713.

Kleinteich, J., Wood, S.A., Küpper, F.C., Camacho, A., Quesada, A., Frickey, T. \& Dietrich, D.R. 2012. Temperature related changes in polar cyanobacterial mat diversity and toxin production. Nature Climate Change, 10.1038/nclimate1418.
Kopaloví, K. \& van de Vijver, B. 2013. Structure and ecology of the freshwater diatom communities from Byers Peninsula, Livingston Island, South Shetland Islands. Antarctic Science, 25, 10.1017/ S0954102012000764.

Lewis Smith, R.I. 1985. Nothofagus and other trees stranded on islands in the Atlantic sector of the Southern Ocean. British Antarctic Survey Bulletin, No. 66, 47-55.

Lewis Smith, R.I. \& Øvstedal, D.O. 1991. The lichen genus Stereocaulon in Antarctica and South Georgia. Polar Biology, 11, 91-102.

Lewis Smith, R.I. \& Simpson, H.W. 1987. Early nineteenth century sealer refuges on Livingston Island, South Shetland islands. British Antarctic Bulletin, No. 74, 49-72.

LindSAY, D.C. 1969a. Further data on Antarctic Usneaceae. British Antarctic Survey Bulletin, No. 20, 23-40.

Lindsay, D.C. 1969b. New records for Antarctic Umbilicariaceae. British Antarctic Survey Bulletin, No. 21, 61-69.

LinDSAY, D.C. 1971a. Notes on Antarctic lichens: I. New records for Buellia and Rinodina. British Antarctic Survey Bulletin, No. 24, 11-19.

LindSAY, D.C. 1971b. Vegetation of the South Shetland Islands. British Antarctic Survey Bulletin, No. 25, 59-83.

Lindsay, D.C. 1973. Notes on Antarctic lichens: Vll. The genera Cetraria Hoffm., Hypogymnia (Nyl.) Nyl., Menegazzia Massal., Parmelia Ach. and Platismatia Culb. et Culb. British Antarctic Survey Bulletin, No. 36, 105-114.

LomAs, S.A. 1999. A Lower Cretaceous clastic slope succession, Livingston Island, Antarctica: sand-body characteristics, depositional processes and implications for slope apron depositional models. Sedimentology, 46, 477-504.

López-Bueno, A., Tamames, J., Velázquez, D., Moya, A., Quesada, A. \& Alcami, A. 2009. High diversity of the viral community from an Antarctic lake. Science, 326, 858-861.

López-Martínez, J., Serrano, E. \& Martínez de Pisón, E. 1996c. Geomorphological features of the drainage system. In LóPEZ-MARTínEZ, J., Thomson, M.R.A. \& Thomson, J.W., eds. Geomorphological map of Byers Peninsula, Livingston Island. BAS GEOMAP Series, Sheet 5-A, Scale 1:25 000. Cambridge: British Antarctic Survey, 15-19.

López-Martínez, J., Thomson, M.R.A. \& Thomson, J.W. 1996a. Geomorphological map of Byers Peninsula, Livingston Island. BAS GEOMAP Series, Sheet 5-A, Scale 1:25 000 with supplementary text. Cambridge: British Antarctic Survey, 65 pp.

López-Martínez, J., Martínez de Pisón, E., Serrano, E. \& Arche, A. 1995. Geomorphological map of Byers Peninsula, Livingston Island. BAS Geomap Series 5-A. Scale 1:25 000. Cambridge: British Antarctic Survey.

López-Martínez, J., Hathway, B., Lomas, S., Martínez de Pisón, E. \& ARCHE, A. 1996b. Structural geomorphology and geological setting. In López-Martínez, J., Thomson, M.R.A. \& Thomson, J.W., eds. Geomorphological map of Byers Peninsula, Livingston Island. BAS GEOMAP Series, Sheet 5-A, Scale 1:25 000. Cambridge: British Antarctic Survey, 9-14.

López-Martínez, J., Serrano, E., Schmid, T., Mink, S. \& LinÉs, C. 2012. Periglacial processes and landforms in the South Shetland Islands (northern Antarctic Peninsula region). Geomorphology, 155/156, 62-79.

Lyons, W.B., Welch, K.A., Welch, S.A., Camacho, A., Rochera, C., Michaud, L., Dewit, R. \& CARey, A.E. 2013. Geochemistry of streams from Byers Peninsula, Livingston Island. Antarctic Science, 25, 10.1017/S0954102012000776.

Machado, A., Chemale, F., Conceição, R.V., Kawaskita, K., Morata, D., Oteiza, O. \& van Schmus, W.R. 2005b. Modeling of subduction components in the Genesis of the Meso-Cenozoic igneous rocks from the South Shetland Arc, Antarctica. Lithos, 82, 435-453.

Machado, A., Lima, E.F., Chemale, F., Morata, D., Oteiza, O., Almeida, D.P.M., Figuereido, A.M.G., Alexandre, F.M. \& Urrutia, J.L. 2005a. Geochemistry constraints of Mesozoic-Cenozoic calc-alkaline magmatism in the South Shetland Arc, Antarctica. Journal of South American Earth Sciences, 18, 407-425. 
Martínez de Pisón, E., Serrano, E., Arche, A. \& López-Martínez, J. 1996a. Glacial geomorphology. In López-Martínez, J., Thomson, M.R.A. \& Thomson, J.W., eds. Geomorphological map of Byers Peninsula, Livingston Island. BAS GEOMAP Series, Sheet 5-A, Scale 1:25 000. Cambridge: British Antarctic Survey, 23-27.

Martínez de Pisón, E., López-Martínez, J., Serrano, E. \& Arche, A. 1996b. Geomorphological evolution. In López-Martínez, J., Thomson, M.R.A. \& Thomson, J.W., eds. Geomorphological map of Byers Peninsula, Livingston Island. BAS GEOMAP Series, Sheet 5-A, Scale 1:25 000. Cambridge: British Antarctic Survey, 52-54.

Matzer, M., Mayrhofer, H. \& Scheidegger, C.H. 1994. Notes on Amandinea petermannii comb. nov. (Physciaceae) from Antarctica. Lichenologist, 26, 39-46.

Michalchuck, B.R., Anderson, J.B., Wellner, J.S., Manley, P.L., MajewsKi, W. \& Bонату, S. 2009. Holocene climate and glacial history of the northeastern Antarctic Peninsula: the marine sedimentary record from a long SHALDRIL core. Quaternary Science Reviews, 28, 3049-3065.

Moura, P.A., Francelino, M.R., Schaefer, C.E.G.R., Simas, F.N.B. \& DE MendonçA, B.A.F. 2012. Distribution and characterization of soils and landform relationships in Byers Peninsula, Livingston Island, Maritime Antarctica. Geomorphology, 155/156, 45-54.

Nakai, R., Shibuya, E., Justel, A., Rixo, E., Quesada, A., Elvevold, S., Holmén, K., Kobayashi, F., Imasaka, Y., Shi, G.-Y., Amano, Y., Iwatsuki, T. \& Naganima, T. 2013. Phylogeographic analysis of filetrable bacteria with special reference to Rhizobiales strains that occur in cryospheric habitats. Antarctic Science, 25, 10.1017/S0954102012000831.

Navas, A., Soto, J. \& López-Martínez, J. 2005. Radionuclides in soils of Byers Peninsula, South Shetland Islands, Western Antarctica. Applied Radiation and Isotopes, 62, 809-816.

Navas, A., López-Martínez, J., Casas, J., Machín, J., Durán, J.J., Serrano, E. \& Cuchi, J.A. 2006. Soil characteristics along a transect on raised marine surfaces on Byers Peninsula, Livingston Island, South Shetland Islands. In Fütterer, D.K., Damaske, D., Kleinschmidt, G., Miller, H. \& Tessensohn, F., eds. Antarctica contributions to global earth science. Berlin: Springer, 467-474.

Navas, A., López-Martínez, J., Casas, J., Machín, J., Durán, J.J., Serrano, E., Cuchi, J.A. \& Milk, S. 2008. Soil characteristics on varying lithological substrates in the South Shetland Islands, maritime Antarctica. Geoderma, 144, 123-139.

Nielsen, U.N., Wall, D.H., Li, G., Toro, M., Adams, B.J. \& Virginia, R.A. 2011. Nematode communities of Byers Peninsula, Livingston Island, maritime Antarctica. Antarctic Science, 23, 349-357.

Ochyra, R., Lewis Smith, R.I. \& Bednarek-Ochyra, H. 2008. The illustrated moss flora of Antarctica. Cambridge: Cambridge University Press, $685 \mathrm{pp}$.

Orheim, O. 1971. Glaciological studies at Deception Island and Livingston Island. Antarctic Journal of United States, 6(4), 85.

OrLando, H.A. 1968. A new Triassic flora from Livingston Island, South Shetland Islands. British Antarctic Survey Bulletin, No. 16, 1-13.

OteízA, O. 1999. Petrogénesis del magmatismo básico del MesoCenozoico en la Península Byers, Isla Livingston (Archipiélago de Shetland del Sur, Antártica). MSc thesis, University of Chile, 100 pp. [Unpublished]

Pankhurst, R.J., Weaver, S.D., Brook, M. \& Saunders, A.D. 1979. K-Ar chronology of Byers Peninsula, Livingston Island, South Shetland Islands. British Antarctic Survey Bulletin, No. 49, 277-282.

Parica, C.A., Salani, F.M., Vera, E., Remesal, M. \& Césari, S.N. 2007. Geología de la formación Cerro Negro (Cretácico) en Isla Livingston: aportes a su geocronología y contenido paleontológico. Revista de la Asociación Geológica Argentina, 62, 553-567.

Pearce, D.A. \& Laybourn-Parry, J. 2012. Antarctic lakes as models for the study of microbial biodiversity, biogeography and evolution. In Rogers, A.D., Johnston, N.M., Murphy, E.J. \& Clarke, A., eds. Antarctic ecosystems: an extreme environment in a changing world. Chichester: John Wiley, 10.1002/9781444347241.ch3
Pearson, M., Stehberg, R., Zarankin, A., Senatore, M.X. \& Gatica, C. 2008. Sealer's sledge excavated on Livingston Island, South Shetland Islands. Polar Record, 44, 362-364.

Pearson, M., Stehberg, R., Zarankin, A., Senatore, M.X. \& Gatica, C. 2010. Conserving the oldest historic sites in the Antarctic: the challenges in managing the sealing sites in the South Shetland Islands. Polar Record, 46, 57-64.

Pertierra, L.R., Hughes, K.A., Benayas, J., Justel, A. \& Quesada, A. 2013 a. Environmental management of a scientific field camp in Maritime Antarctica: reconciling research impacts with conservation goals in remote ice-free areas. Antarctic Science, 25, 10.1017/S0954102012001083.

Pertierra, L., Lara, F., Tejedo, P., Quesada, A. \& Benayas, J. 2013 b. Rapid denudation processes in cryptogamic communities from Maritime Antarctica subjected to human trampling. Antarctic Science, 25, 10.1017/S095410201200082X.

Petz, W., Valbonesi, A. \& Quesada, A. 2005. Ciliate biodiversity in freshwater environments of maritime and continental Antarctic. Terra Antarctica Reports, 11, 43-50.

Petz, W., Valbonesi, A., Schiftner, U., Quesada, A. \& Ellis-Evans, J.C. 2007. Ciliate biogeography in Antarctic and Arctic freshwater ecosystems: endemism or global distribution of species? FEMS Microbiology Ecology, 59, 396-408.

Pimpirev, C. \& Vangelov, D. 1999. Ancient subaqueous mouth bar type delta system, Byers Group, Livingston Island, Antarctica. Sofia University Yearbook, Faculty of Geology and Geography, 90, 29-43.

PirRIE, D. \& CRAme, J.A. 1995. Late Jurassic paleogeography and anaerobic-dysaerobic sedimentation in the nothern Antarctic Peninsula. Journal of the Geological Society of London, 152, 469-480.

Pla-Rabes, S., Toro, M., van de Vijver, B., Rochera, C., Villaescusa, J.A., Camacho, A. \& Quesada, A. 2013. Stability and endemicity of benthic diatom assemblages from different substrates on a maritime stream on Byers Peninsula, Livingston Island, Antarctica: the role of climate variability. Antarctic Science, 25, 10.1017/S0954102012000922.

Poblete, F., Arriagada, C., Roperch, P., Astudillo, N.M., Hervé, F., Kraus, S. \& Le-Roux, J.P. 2011. Paleomagnetism and tectonics of the South Shetland Islands and the northern Antarctic Peninsula. Earth and Planetary Science Letters, 302, 299-313.

Quesada, A., Camacho, A., Rochera, C. \& Velázquez, D. 2009. Byers Peninsula: a reference site for coastal, terrestrial and limnetic ecosystem studies in maritime Antarctica. Polar Science, 3, 181-187.

Quesada, A., Fernández-Valiente, E., Hawes, I. \& Howard-Williams, C. 2008. Benthic primary production in polar lakes and rivers. In VINCENT, W.F. \& Laybourn-Parry, J., eds. Polar lakes and rivers: limnology of Arctic and Antarctic aquatic ecosystems. Oxford: Oxford University Press, 179-196.

Quesada, A., Vincent, W.F., Kaup, E., Hobbie, J.E., Laurion, I., Pienitz, R., López-Martínez, J. \& Durán, J.J. 2006. Landscape control of high latitude lakes in a changing climate. In Bergstrom, D.M., Convey, P. \& Huiskes, A.H.L., eds. Trends in Antarctic terrestrial and limnetic ecosystems. Dordrecht: Springer, 221-252.

Rengifo-Herrera, C., Ortega-Mora, L.M., Gómez-Bautista, M., GarcíaMoreno, G.T., García-Párraga, D., Castro-Urda, J. \& Pedraza-Díaz, S. 2011. Detection and characterization of a Cryptosporidium isolate from a southern elephant seal (Mirounga leonina) from the Antarctic Peninsula. Applied and Environmental Microbiology, 77, 1524-1527.

Richard, K.J., Convey, P. \& Block, W. 1994. The terrestrial arthropod fauna of the Byers Peninsula, Livingston-Island, South Shetland Islands. Polar Biology, 14, 371-379.

Rico, E. \& Quesada, A. 2013. Distribution and ecology of chironomids (Diptera, Chironomidae) on Byers Peninsula, Maritime Antarctica. Antarctic Science, 25, 10.1017/S095410201200096X.

Rochera, C., Villaescusa, J.A., Velázquez, D., Fernández-Valiente, E., Quesada, A. \& CAmacho, A. 2013b. Vertical structure of bi-layered microbial mats from Byers Peninsula, Maritime Antarctica. Antarctic Science, 25, 10.1017/S0954102012000983. 
Rochera, C., Justel, A., Fernández-Valiente, E., Bañón, M., Rico, E., Toro, M., CAmacho, A. \& Quesada, A. 2010. Interannual meteorological variability and its effects on a lake from maritime Antarctica. Polar Biology, 33, 1615-1628.

Rochera, C., Toro, M., Camacho, A., Rico, E., Fernández-Valiente, E., Villaescusa, J.A., Picazo, A., Quesada, A. \& Camacho, A. 2013a. Structure of planktonic microbial communities along a trophic gradient in lakes of Byers Peninsula, South Shetland Islands. Antarctic Science, 25, 10.1017/S0954102012000971.

Rochera, C., Villaescusa, J.A., Díazmazip, M.E., Gil-Delgado, J.A., Toro, M., Rico, E., Velázquez, D., Quesada, A. \& Camacho, A. 2011. Interacciones bióticas en lagos Antárticos. Investigaciones derivadas del proyecto LIMNOPOLAR en la Península Byers (Antártida marítima). Ecosistemas, 20, 23-32.

Rodríguez, P. \& Rico, E. 2008. A new freshwater oligochaete species (Clitellata: Enchytraeidae) from Livingston Island, Antarctica. Polar Biology, 31, 1267-1279.

Sancho, L.G., Kappen, L. \& Schroeter, B. 1992. The lichen genus Umbilicaria on Livingston Island, South Shetland Islands, Antarctica. Antarctic Science, 4, 189-196.

Schiaffino, M.R., Unrein, F., Gasol, J.M., Massana, R., Balagué, V. \& IZAGUIRRE, I. 2011. Bacterial community structure in a latitudinal gradient of lakes: the roles of spatial versus environmental factors. Freshwater Biology, 56, 1973-1991.

Serrano, E. 2003. Natural landscape and geoecological belts on ice free areas of the maritime Antarctica (South Shetland Islands). AGE Bulletin, 35, 5-32.

Serrano, E., Martínez de Pisón, E. \& López-Martínez, J. 1996. Periglacial and nival landforms and deposits. In López-Martínez, J., Thomson, M.R.A. \& Thomson, J.W., eds. Geomorphological map of Byers Peninsula, Livingston Island. BAS GEOMAP Series, Sheet 5-A, Scale 1:25 000. Cambridge: British Antarctic Survey, 28-34.

SGE, UAM \& BAS. 1993. Byers Peninsula, Livingston Island. Topographic map, Antarctic Cartography, Scale 1:25 000. Madrid: Servicio de Geografía del Ejército, Universidad Autónoma de Madrid and British Antarctic Survey.

Smellie, J.L., Davies, R.E.S. \& Thomson, M.R.A. 1980. Geology of a Mesozoic intra-arc sequence on Byers Peninsula, Livingston Island, South Shetland Islands. British Antarctic Survey Reports, No. 50, $55-76$.

Stehberg, R. 2008. Protection and preservation of the oldest sites of the Antarctic; the case of Fildes Peninsula and Byers Peninsula in the South Shetland Islands. In BAAR, S. \& Chaplin, P., eds. Historical Polar bases; preservation and management. Oslo: International Polar Heritage Committee, 85-93.

Stehberg, R., Pearson, M., Blanchette, R. \& Jurgens, J.A. 2009. A further note on a sealer's sledge, discovered on Livingston Island, South Shetland Islands. Polar Record, 45, 275-275.

Sugden, D.E. \& John, B.S. 1973. The ages of glacier fluctuations in the South Shetland Islands, Antarctica. In van Zinderen, E.M., ed. Paleoecology of Africa and of the surrounding islands and Antarctica. Cape Town: Balkema, 141-159.

Tejedo, P., Justel, A., Rico, E., Benayas, J. \& Quesada, A. 2005. Measuring impacts on soils by human activity in an Antarctic Special Protected Area. Terra Antartica Reports, 11, 57-62.

Tejedo, P., Justel, A., Benayas, J., Rico, E., Convey, P. \& Quesada, A. 2009. Soil trampling in an Antarctic Specially Protected Area: tools to assess levels of human impact. Antarctic Science, 21, 229-236.

Tejedo, P., Pertierra, L., Benayas, J., Convey, P., Justel, A. \& Quesada, A. In press. Trampling on maritime Antarctica: can soil ecosystems be effectively protected through existing codes of conduct? Polar Research.

Tном, G. 1978. Disruption of bedrock by the growth and collapse of ice lenses. Journal of Glaciology, 20, 571-575.
Thomson, M.R.A. 1992. Stratigraphy and age of the pre-Cenozoic stratified rocks of the South Shetland Islands: review. In LópezMartínez, J., ed. Geología de la Antártida Occidental. Simposios Tomo 3. III Congreso Geológico de España y VII Congreso Latinoamericano de Geología. Madrid: Comisión Interministerial de Ciencia y Tecnología, 75-92.

Thomson, M.R.A. \& López-Martínez, J. 1996. Geomorphological map of Byers Peninsula, Livingston Island; introduction. In LóPEZ-MARTínez, J., Thomson, M.R.A. \& Thomson, J.W., eds. Geomorphological map of Byers Peninsula, Livingston Island. BAS GEOMAP Series, Sheet 5-A, Scale 1:25 000. Cambridge: British Antarctic Survey, 1-4.

Toro, M., Camacho, A., Rico, E., Rochera, C., Velázquez, D., Dominguez, J.A. \& QuesadA, A. 2008. Implicaciones del cambio climático en el funcionamiento de los ecosistemas antárticos: los lagos como centinelas de la variación ambiental. Ingeniería Civil, 149, 1-12.

Toro, M., Granados, I., Pla, S., Giralt, S., Antoniades, D., Galán, L., Martínez Cortizas, A., Lim, H.S. \& Appleby, P.G. 2013. Chronostratigraphy of the sedimentary record of Limnopolar Lake, Byers Peninsula, Livingston Island, Antarctica. Antarctic Science, 25, 10.1017/S095410202000788.

Toro, M., Camacho, A., Rochera, C., Rico, E., Bañon, M., FernandezValiente, E., Marco, E., Justel, A., Avendano, M.C., Ariosa, Y., VinCENT, W.F. \& QuesADA, A. 2007. Limnological characteristics of the freshwater ecosystems of Byers Peninsula, Livingston Island, in maritime Antarctica. Polar Biology, 30, 635-649.

Torres, T.G., Valenzuela, E. \& Gonzalez, I. 1982. Paleoxilologia de peninsula Byers, Isla Livingston, Antarctica. Actas III Congreso Geológico Chileno, 2, 321-342.

Upson, R., Read, D.J. \& Newsham, K.K. 2007. Widespread association between the ericoid mycorrhizal fungus Rhizoscyphus ericae and a leafy liverwort in the maritime and sub-Antarctic. New Phytologist, 176, 460-471.

Valenzuela, E. \& Hervé, F. 1972. Geology of Byers Peninsula, Livingston Island, South Shetland Islands. In ADIE, R.J., ed. Antarctic geology and geophysics. Oslo: Universitetsforlaget, 83-89.

Van De Vijver, B. \& Zidarova, R. 2011. Five new taxa in the genus Pinnularia sectio Distantes (Bacillariophyta) from Livingston Island (South Shetland Islands). Phytotaxa, 24, 39-50.

Van de ViJver, B., Zidarova, R. \& De HaAn, M. 2011. Four new Luticola taxa (Bacillariophyta) from the South Shetland Islands and James Ross Island (Maritime Antarctic Region). Nova Hedwigia, 92, 137-158.

Van de Vijver, B., Agius, J.T., Gibson, J.A.E. \& Quesada, A. 2009. An unusual spine-bearing Pinnularia species from the Antarctic Livingston Island (South Shetland Islands). Diatom Research, 24, 431-441.

Velázquez, D., Frías, A., Lezcano, M.A. \& Quesada, A. 2013. Ecological relationships and stoichiometry within a maritime Antarctic watershed. Antarctic Science, 25, 10.1017/S0954102012000843.

Velázquez, D., Rochera, C., Camacho, A. \& Quesada, A. 2011. Temperature effects on carbon and nitrogen metabolism in some Maritime Antarctic freshwater phototrophic communities. Polar Biology, 34, 1045-1055.

VerA, E.I. 2007. A new species of Ashicaulis Tidwell (Osmundaceae) from Aptian strata of Livingston Island, Antarctica. Cretaceous Research, 28, 500-508.

VerA, E.I. 2009. Alienopteris livingstonensis gen. et sp nov., enigmatic petrified tree fern stem (Cyatheales) from the Aptian Cerro Negro Formation, Antarctica. Cretaceous Research, 30, 401-410.

VerA, E.I. 2010. A new specimen of Millerocaulis (Osmundales: Osmundaceae) from the Cerro Negro Formation (Lower Cretaceous), Antarctica. Revista del Museo Argentino de Ciencias Naturales "Bernardino Rivadavia", nueva serie, 12, 41-46.

VERA, E.I. 2011. Livingstonites gabrielae gen. et sp. nov., permineralized moss (Bryophyta: Bryopsida) from the Aptian Cerro Negro formation of Livingston Island (South Shetland Islands, Antarctica). Ameghiniana, 48, 122-128. 
VERA, E.I. 2012. Millerocaulis tekelili sp. nov., a new species of osmundalean fern from the Aptian Cerro Negro Formation (Antarctica). Alcheringa, 36, 35-45.

VerA, M. 2013. Distribution and reproductive capacity of Deschampsia antarctica and Colobanthus quitensis on Byers Peninsula, Livingston Island, South Shetland Islands, Antarctica. Antarctic Science, 25, 10.1017/S0954102012000995.

Vieira, G., Bockheim, J., Guglielmin, M., Balks, M., Abramov, A.A., Boelhoumers, J., Cannone, N., Ganzert, L., Gilichinsky, D.A., Goryachion, S., López-Martínez, J., Meiklejohn, I., Raffi, R., Ramos, M., Schaefer, C., Serrano, E., Simas, F., Sletten, R. \& Wagner, D. 2010. Thermal state of permafrost and active-layer monitoring in the Antarctic: advances during the International Polar Year 2007-2009. Permafrost and Periglacial Processes, 21, 182-197.

Villaescusa, J.A., Casamayor, E.O., Rochera, C., Quesada, A., Michaud, L. \& Cамасно, A. 2013. Heterogeneous vertical structure of the bacterioplankton community in a non-stratified Antarctic lake. Antarctic Science, 25, 10.1017/S0954102012000910.

Villaescusa, J.A., Casamayor, E.O., Rochera, C., Velázquez, D., Chicote, A., Quesada, A. \& Cамacho, A. 2010. A close link between bacterial community composition and environmental heterogeneity in maritime Antarctic lakes. International Microbiology, 13, 67-77.

Vincent, W.F. \& QuesAdA, A. 2012. Cyanobacteria in high latitude lakes, rivers and seas. In WhitTon, B.A., ed. Ecology of cyanobacteria II: their diversity in space and time. Dordrecht: Springer, 371-385.

Vincent, W.F., Hobbie, J.E. \& Laybourn-Parry, J. 2008. Introduction to the limnology of high latitude lake and river ecosystems. In VINCENT, W.F. \& Laybourn-Parry, J., eds. Polar lakes and rivers: limnology of Arctic and Antarctic aquatic ecosystems. Oxford: Oxford University Press, 1-23.
Watts, D.R., Watts, G.C. \& Bramall, A.M. 1984. Cretaceous and Early Tertiary paleomagnetic results from the Antarctic Peninsula. Tectonics, 3, 333-346.

Wirtz, N., Lumbsch, H.T., Green, T.G.A., Türk, R., Pintado, A., Sancho, L. \& SChroeter, B. 2003. Lichen fungi have low cyanobiont selectivity in maritime Antarctica. New Phytologist, 160, 177-183.

Yoo, C.M. \& Choе, M.Y. 2000. Provenance of the Lower Cretaceous President Beaches Formation, Livingston Island, South Shetland Islands, West Antarctica. Korean Journal of Polar Research, 11, 27-34.

Zarankin, A. \& Senatore, M.X. 2005. Archaeology in Antarctica: nineteenth-century capitalism expansion strategies. International Journal of Historical Archaeology, 9, 43-56.

Zheng, X.S., Liu, J., LeE, J.I. \& Hwang, J. 1998a. Geochemical characteristics of the Mesozoic volcanic rocks from the Byers Peninsula of Livingston Island, West Antarctica. Acta Petrologica Sinica, 14, 503-519. [In Chinese with English summary].

Zheng, X.S., SÀbat, F., Casas, J.M. \& Pallàs, R. 1995. Volcanic geology of Livingston Island, West Antarctica: a summary. Antarctic Research, 7, 18-29. [In Chinese with English summary].

Zheng, X.S., Sang, H.Q., Qiu, J., Liu, J., Lee, J.I. \& Hwang, J. 1998 b. Isotopic age of the volcanic rock in Byers Peninsula, Livingston Island, West Antarctica. Chinese Journal of Polar Research, 10, 1-10. [In Chinese with English summary.]

Zidarova, R., Kopaloví, K. \& van de Vijver, B. 2012. The genus Pinnularia (Bacillariophyta) excluding the section Distantes on Livingston Island (South Shetland Islands) with the description of twelve new taxa. Phytotaxa, 44, 11-37.

Zidarova, R., van de Vijver, B., Quesada, A. \& De Haan, M. 2010. Revision of the genus Hantzschia (Bacillariophyceae) on Livingston Island (South Shetland Islands, Southern Atlantic Ocean). Plant Ecology and Evolution, 143, 318-333. 